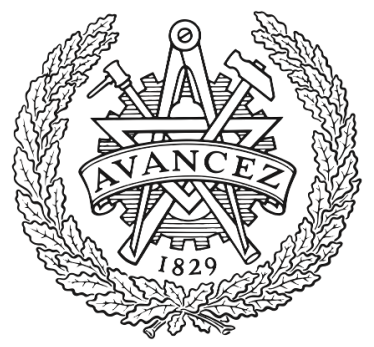

CHALMERS

UNIVERSITY OF TECHNOLOGY

\title{
On the Reaction Mechanism of Direct $\mathbf{H}<$ inf $>\mathbf{2}</$ inf $>\mathbf{O}<$ inf $>2<$ inf $>$ Formation over Pd Catalysts
}

Downloaded from: https://research.chalmers.se, 2023-04-26 10:47 UTC

Citation for the original published paper (version of record):

Chen, L., Medlin, J., Grönbeck, H. (2021). On the Reaction Mechanism of Direct $\mathrm{H}<\inf >2<\inf >\mathrm{O}<\inf >2</ \inf >$ Formation over Pd Catalysts. ACS Catalysis, 11(5): 2735-2745. http://dx.doi.org/10.1021/acscatal.0c05548

N.B. When citing this work, cite the original published paper. 


\title{
On the Reaction Mechanism of Direct $\mathrm{H}_{2} \mathrm{O}_{2}$ Formation over Pd Catalysts
}

\author{
Lin Chen,* J. Will Medlin, and Henrik Grönbeck*
}

Cite This: ACS Catal. 2021, 11, 2735-2745

Read Online

ABSTRACT: Hydrogen peroxide $\left(\mathrm{H}_{2} \mathrm{O}_{2}\right)$ is an effective green oxidant, which is used in many industrial processes. Here, the reaction mechanism for direct formation of $\mathrm{H}_{2} \mathrm{O}_{2}$ from $\mathrm{H}_{2}$ and $\mathrm{O}_{2}$ over $\mathrm{Pd}$ catalysts is studied using density functional theory calculations and mean-field kinetic modeling. The state of the catalyst as a function of reaction conditions is determined from $a b$ initio thermodynamics. It is found that Pd is in a hydride phase during typical reaction conditions. Reaction landscapes are constructed for the reaction over $\mathrm{PdH}(111)$ and $\mathrm{PdH}(211)$. Formation of $\mathrm{H}_{2} \mathrm{O}_{2}$ instead of $\mathrm{H}_{2} \mathrm{O}$ requires that $\mathrm{O}_{2}$ adsorbs and that the surface intermediates $\mathrm{O}_{2}, \mathrm{OOH}$, and $\mathrm{H}_{2} \mathrm{O}_{2}$ do not dissociate. We find that these requirements are fulfilled on the stepped $\mathrm{PdH}(211)$ surface. Surface steps are needed for $\mathrm{O}_{2}$ chemisorption as the adsorption on $\mathrm{PdH}(111)$ is endothermic. The high $\mathrm{H}$ coverage on the surface of the hydride is important to slow down the unwanted scission of the $\mathrm{O}-\mathrm{O}$ bond and promote the desorption of the products.

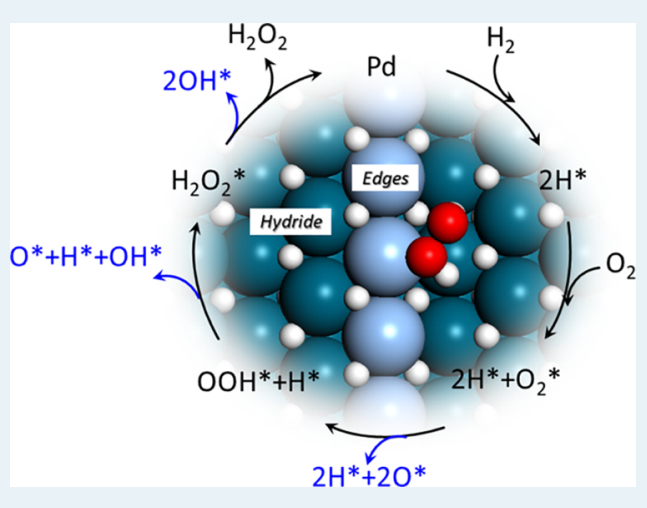
Comparative calculations for the $\mathrm{Pd}(111)$ surface show that this surface is inactive for both $\mathrm{H}_{2} \mathrm{O}_{2}$ and $\mathrm{H}_{2} \mathrm{O}$ formation below room temperature for typical reaction mixtures. Our findings demonstrate the importance of surface steps and high hydrogen coverage for direct synthesis of $\mathrm{H}_{2} \mathrm{O}_{2}$ from $\mathrm{H}_{2}$ and $\mathrm{O}_{2}$ over $\mathrm{Pd}$ catalysts. The results imply that the selectivity of the reaction toward $\mathrm{H}_{2} \mathrm{O}_{2}$ is enhanced by a high partial pressure of $\mathrm{H}_{2}$, which is in agreement with experimental observations.

KEYWORDS: $\mathrm{H}_{2} \mathrm{O}_{2}$, selectivity, $\mathrm{Pd}, \mathrm{PdH}, \mathrm{DFT}$

\section{INTRODUCTION}

Hydrogen peroxide, $\mathrm{H}_{2} \mathrm{O}_{2}$, is a widely used oxidant for liquidphase reactions within, for example, textile bleaching and waste water purification. ${ }^{1}$ Hydrogen peroxide can oxidize organic compounds with $\mathrm{H}_{2} \mathrm{O}$ and $\mathrm{O}_{2}$ as the only byproducts. ${ }^{2}$ This is a clear advantage with respect to nitric acid or chlorinated oxidizers, which may result in toxic byproducts. ${ }^{2}$ Currently, the production of $\mathrm{H}_{2} \mathrm{O}_{2}$ is largely dependent on the anthraquinone oxidation process (AO process) with a series of reduction/ oxidation steps. ${ }^{3}$ This large-scale process requires the use of quinones and toxic organic solvents and energy-intensive purification procedures, generating undesirable wastes. ${ }^{4}$ During the past decades, the direct synthesis of $\mathrm{H}_{2} \mathrm{O}_{2}$ from $\mathrm{H}_{2}$ and $\mathrm{O}_{2}$ over transition metals at low temperatures $(275-315 \mathrm{~K})$ has been explored as an appealing alternative production route thanks to its simplicity and low environmental impact. Moreover, these processes can be operated in a small/middle scale, and $\mathrm{H}_{2} \mathrm{O}_{2}$ can be produced close to the location of usage. ${ }^{4,5}$

Direct synthesis of $\mathrm{H}_{2} \mathrm{O}_{2}$ has not yet emerged at an industrial scale primarily because of its low selectivity toward $\mathrm{H}_{2} \mathrm{O}_{2}{ }^{6}$. The low selectivity comes mainly from irreversible $\mathrm{O}-$ $\mathrm{O}$ bond cleavage and the subsequent unselective hydrogenation of the intermediates to $\mathrm{H}_{2} \mathrm{O}{ }^{7}$ The reaction cycle following a Langmuir-Hinshelwood mechanism is shown in
Figure 1. The cycle starts by adsorption of $\mathrm{H}_{2}$ forming atomic hydrogen. The next step involves molecular adsorption of $\mathrm{O}_{2}$. From this state, $\mathrm{H}_{2} \mathrm{O}_{2}$ can be formed by subsequent hydrogenation and eventual desorption of the product. The challenge is the unwanted $\mathrm{O}-\mathrm{O}$ cleavage and subsequent $\mathrm{H}_{2} \mathrm{O}$ formation. The $\mathrm{O}-\mathrm{O}$ bond can be cleaved at different stages of hydrogenation, and the barrier for $\mathrm{O}-\mathrm{O}$ rupture is reduced with an increasing degree of hydrogenation.

Palladium catalysts have shown higher selectivity for direct $\mathrm{H}_{2} \mathrm{O}_{2}$ synthesis than other transition-metal catalysts, such as $\mathrm{Pt}^{8}$ and $\mathrm{Au}^{9}$ The highest selectivity reported to date for direct synthesis of $\mathrm{H}_{2} \mathrm{O}_{2}$ over catalysts of supported $\mathrm{Pd}$ nanoparticles is $80 \%$. ${ }^{1}$ However, the rate of $\mathrm{H}_{2} \mathrm{O}_{2}$ production selectivities appears to depend strongly on factors, such as reactant pressures, ${ }^{10}$ particle size, ${ }^{11}$ solvents (e.g., water and ethanol), ${ }^{12}$ and promoters (e.g., the presence of halides). ${ }^{4,13}$ In particular, the activity of the $\mathrm{Pd}$ catalysts has been found to depend strongly on the $\mathrm{H}_{2} / \mathrm{O}_{2}$ ratio and the reaction temperature. ${ }^{12}$

Received: December 17, 2020

Revised: January 25, 2021

Published: February 12, 2021 
The literature concerning the $\mathrm{H}_{2} / \mathrm{O}_{2}$ ratio is, however, not conclusive. References ${ }^{4,10,14}$ indicate that a high $\mathrm{H}_{2} / \mathrm{O}_{2}$ ratio is needed to enhance the $\mathrm{H}_{2} \mathrm{O}_{2}$ rate and selectivity, whereas refs ${ }^{15,16}$ indicate that a $\mathrm{H}_{2} / \mathrm{O}_{2}$ ratio close to 1 gives the highest rate and selectivity. Regarding the effect of temperature, experimental studies agree that the $\mathrm{H}_{2} \mathrm{O}_{2}$ selectivity is favored at low temperatures. ${ }^{12,17}$ It is known that $\mathrm{O}_{2}$ dissociates above $200 \mathrm{~K}$ over metallic Pd. ${ }^{18-20}$ This indicates that the active site for direct synthesis of $\mathrm{H}_{2} \mathrm{O}_{2}$ should be different from the metallic Pd state. However, the underlying mechanism for the reaction has not yet been well understood.

Improving the $\mathrm{H}_{2} \mathrm{O}_{2}$ selectivity over $\mathrm{Pd}$ catalysts would benefit from an atomic-level understanding of the reaction mechanism. Although $\mathrm{H}_{2} \mathrm{O}_{2}$ formation over $\mathrm{Pd}$ systems has been investigated from first principles, ${ }^{7,21}$ we are not aware of studies where the hydride phase has been considered. Here, we investigate the reaction paths for direct formation of $\mathrm{H}_{2} \mathrm{O}_{2}$ from $\mathrm{H}_{2}$ and $\mathrm{O}_{2}$ over $\mathrm{Pd}$ catalysts by the combination of density functional theory calculations and first-principle-based kinetic modeling. Evaluation of reaction kinetics is needed to understand the kinetic consequences of different reaction paths. The state of the Pd catalysts under reaction conditions is determined by constructing a surface phase diagram with respect to the chemical potentials of $\mathrm{H}_{2}$ and $\mathrm{O}_{2}$. We find that $\mathrm{Pd}$ is preferably in a hydride state under typical reaction conditions. A high coverage of hydrogen is found to be important for the selectivity of the reaction as adsorbed hydrogen prevents $\mathrm{O}-\mathrm{O}$ scission. The adsorption energy of $\mathrm{O}_{2}$ is endothermic on $\mathrm{PdH}(111)$, which suggests that the reaction takes place over steps. We explore $\operatorname{PdH}(211)$ as a model for low-coordinated sites and find that $\mathrm{O}_{2}$ adsorbs exothermically over this step and can be hydrogenated with low barriers. The kinetic analysis reveals a selectivity of about 0.3 over the $\mathrm{PdH}(211)$ step, which is in reasonable agreement with experiments.

\section{COMPUTATIONAL METHODS}

First-Principles Calculations. Spin-polarized density functional theory calculations are performed with the Vienna ab initio simulation package (VASP). ${ }^{22-26}$ The Kohn-Sham orbitals are expanded with plane waves using a $450 \mathrm{eV}$ energy cutoff, and the interaction between the valence electrons and the cores is described with the plane augmented wave approach. $^{27,28}$ The numbers of valence electrons considered in the calculations are $10(\mathrm{Pd}), 6(\mathrm{O})$, and $1(\mathrm{H})$. The exchange-correlation effects are described within the generalized gradient approximation according to Perdew, Burke, and Ernzerhof (PBE). ${ }^{29}$ The D3 approach proposed by Grimme and co-workers ${ }^{30,31}$ is added to describe the vdW interactions. The calculated lattice constants of bulk $\mathrm{Pd}$ and $\mathrm{PdH}$ within $\mathrm{PBE}+\mathrm{D} 3$ are 3.89 and $4.08 \AA$, respectively, which agree well with the experimental values of $3.89 \AA$ (Pd) and $4.09 \AA$ $(\mathrm{PdH}) .^{32}$ Structures are optimized with the conjugate gradient method, and geometries are considered to be converged when the electronic energy difference between subsequent steps is lower than $1 \times 10^{-5} \mathrm{eV}$ and the largest force is lower than 0.03 $\mathrm{eV} / \AA$.

$\mathrm{Pd}$ and $\mathrm{PdH}$ surfaces are built from the theoretical lattice constants. The $\operatorname{Pd}(111)$ and $\operatorname{PdH}(111)$ surfaces are modeled by periodically repeated $p(3 \times 3)$ surface cells. The stepped $\mathrm{PdH}(211)$ surface is used to model the reactions over edge sites of typical $\mathrm{Pd}$ nanoparticles. The $\mathrm{PdH}(211)$ surface is considered using a $p(1 \times 2)$ surface cell. The $\operatorname{PdH}(211)$ step joins (100) and (111) microfacets. All surface slabs are constructed with four-atomic layers, and repeated slabs are separated by $12 \AA$ of vacuum. The Brillouin zone is sampled using the Monkhorst-Pack ${ }^{33}$ scheme with a $4 \times 4 \times 1 k$-point for all considered surface cells. As the experimental stoichiometry of $\beta$-phase palladium hydride is $\mathrm{PdH}_{0.7}{ }^{34}$ hydrogen atoms are randomly removed from the $\mathrm{PdH}$ surface slabs to obtain configurations with a $\mathrm{H} / \mathrm{Pd}$ ratio of $\sim 0.7$. $\mathrm{H}$ is preferably adsorbed at surface sites, ${ }^{35}$ and the considered $\mathrm{PdH}$ surface slabs have a monolayer of $\mathrm{H}$ atoms on the surface.

Reaction barriers are calculated by the climbing image nudged elastic band technique as implemented in the transition-state tools of VASP. ${ }^{36,37}$ Harmonic vibrational frequencies are computed using the finite-difference approach. The surface atoms are fixed during the vibrational analysis. The transition states are confirmed by vibrational analysis showing one imaginary frequency along the reaction coordinate. The vibrational analyses are also used to obtain zero-pointcorrected energies.

The reaction energies $\mathrm{H}_{2}+0.5 \mathrm{O}_{2} \rightarrow \mathrm{H}_{2} \mathrm{O}$ and $\mathrm{H}_{2}+\mathrm{O}_{2} \rightarrow$ $\mathrm{H}_{2} \mathrm{O}_{2}$ are calculated to be -2.28 and $-1.19 \mathrm{eV}$, respectively. These results are in fair agreement with the experimental values $^{38}$ of -2.51 and $-1.41 \mathrm{eV}$, respectively.

Surface Phase Diagram. A surface phase diagram with respect to the metal surface and surrounding gas reservoirs can be constructed to determine the stability of the considered systems. Here, the relative stabilities of $\mathrm{H}_{2}$ and $\mathrm{O}_{2}$ adsorption on $\mathrm{Pd}(111)$ structures are calculated by comparing the Gibbs free energy of adsorption $\left(\Delta G^{\text {ads }}\right) . \Delta G^{\text {ads }}$ is obtained with respect to the clean $\operatorname{Pd}(111)$ surface and evaluated as a function of the chemical potentials for $\mathrm{H}_{2}\left(\mu_{\mathrm{H}_{2}}\right)$ and $\mathrm{O}_{2}\left(\mu_{\mathrm{O}_{2}}\right)$

$$
\begin{aligned}
\Delta G^{\text {ads }}= & \frac{1}{A}\left[G_{\mathrm{N}_{\mathrm{H}, \mathrm{N}_{\mathrm{O}} \mathrm{O} / \mathrm{Pd}(111)}^{\text {surf }}-G_{\mathrm{Pd}(111)}^{\text {surf }}-\Delta N_{\mathrm{Pd}} \mu_{\mathrm{Pd}}^{\text {bulk }}}\right. \\
& \left.-\frac{N_{\mathrm{O}}}{2} \mu_{\mathrm{O}_{2}}-\frac{N_{\mathrm{H}}}{2} \mu_{\mathrm{H}_{2}}\right]
\end{aligned}
$$

where $A$ is the surface area, $G_{\mathrm{N}_{\mathrm{H}} \mathrm{H}, \mathrm{N}_{\mathrm{O}} \mathrm{O} / \mathrm{Pd}(111)}^{\text {usf }}$ is the Gibbs free energy of $\operatorname{Pd}(111)$ with $\mathrm{N}_{\mathrm{H}^{-}}$adsorbed $\mathrm{H}$ atoms and $\mathrm{N}_{\mathrm{O}^{-}}$ adsorbed $\mathrm{O}$ atoms, $G_{\mathrm{Pd}(111)}^{\text {surf }}$ is the Gibbs free energy of clean $\operatorname{Pd}(111)$, and $\Delta N_{\mathrm{Pd}}$ is the difference between the numbers of $\mathrm{Pd}$ atoms in the considered surface and the pristine surface. Surface reconstruction can lead to $\Delta N_{\mathrm{Pd}} \neq 0$, and $\mu_{\mathrm{Pd}}^{\text {bulk }}$ is calculated using the $\mathrm{Pd}$ bulk as a reservoir. The chemical potentials of $\mathrm{H}_{2}\left(\mu_{\mathrm{H}_{2}}\right)$ and $\mathrm{O}_{2}\left(\mu_{\mathrm{O}_{2}}\right)$ can be separated into a total energy term and terms dependent on temperature and pressure. ${ }^{39}$ Thus, $\mu_{\mathrm{H}_{2}}$ and $\mu_{\mathrm{O}_{2}}$ are given by

$$
\mu_{x}\left(T, P_{x}\right)=E_{x}+\Delta \mu_{x}\left(T, P^{\circ}\right)+k_{\mathrm{B}} T \ln \left(\frac{P_{x}}{P^{\circ}}\right)
$$

where $x$ is either $\mathrm{H}_{2}$ or $\mathrm{O}_{2}, P^{\circ}$ is the standard pressure, and $\Delta \mu_{x}\left(T, P^{\circ}\right)$ is the chemical potential at the standard pressure. The stable structure at a given condition $\left(T, P_{\mathrm{O}_{2}}\right.$, and $\left.P_{\mathrm{H}_{2}}\right)$ is given by the structure that minimizes $\Delta G^{\text {ads }}$. The configurational entropy of the $\beta$-phase palladium hydride is estimated from $^{40}$

$$
\Delta S_{\text {conf }}=-N k_{\mathrm{B}}[x \ln (x)+(1-x) \ln (1-x)]
$$

where $x$ is 0.7 and $N$ is the total number of octahedral sites. Thus, the free-energy contribution from the configurational entropy per site $\left(G_{\text {conf }}\right)$ is given by 


$$
G_{\text {conf }}=-k_{\mathrm{B}} T[x \ln (x)+(1-x) \ln (1-x)]
$$

An extended palladium oxide bulk is thermodynamically stable when the oxygen content in the environment is high enough, which gives

$$
\mu_{\mathrm{PdO}}^{\text {bulk }}<\mu_{\mathrm{Pd}}^{\text {bulk }}+\frac{1}{2} \mu_{\mathrm{O}_{2}}
$$

whereas a sufficient hydrogen content will make the reduction of $\mathrm{PdO}$ into $\mathrm{H}_{2} \mathrm{O}$ and $\mathrm{Pd}$ preferred, which leads to

$$
\mu_{\mathrm{Pd}}^{\text {bulk }}+\mu_{\mathrm{H}_{2} \mathrm{O}}<\mu_{\mathrm{PdO}}^{\text {bulk }}+\mu_{\mathrm{H}_{2}}
$$

Combining eqs 2, 5, and 6 gives the stability criterion for $\mathrm{PdO}$ in a mixed atmosphere of $\mathrm{H}_{2}$ and $\mathrm{O}_{2}$

$$
\Delta \mu_{\mathrm{H}_{2}}-\frac{1}{2} \Delta \mu_{\mathrm{O}_{2}}<-2 \Delta E_{\mathrm{PdO}}^{\mathrm{f}}+\Delta E_{\mathrm{H}_{2} \mathrm{O}}^{\mathrm{f}}
$$

Here, $\Delta E_{\mathrm{PdO}}^{\mathrm{f}}$ is the formation energy of $\mathrm{PdO}$ at $0 \mathrm{~K}$ and $\Delta E_{\mathrm{H}_{2} \mathrm{O}}^{\mathrm{f}}$ is the formation energy of $\mathrm{H}_{2} \mathrm{O}$ from $\mathrm{H}_{2}$ and $\mathrm{O}_{2}$.

Microkinetic Modeling. The reaction kinetics is obtained by mean-field microkinetic modeling. The reaction networks are constructed from our proposed reaction mechanism (see below). A set of coupled ordinary differential equations (ODEs) describes the time-dependent coverage of each species $^{41}$

$$
\frac{\mathrm{d} \theta_{i}}{\mathrm{~d} t}=\sum_{j} r_{j}(\vec{\theta}) n_{j, i}
$$

where $\theta_{i}$ is the fractional coverage of species $i, r_{j}(\vec{\theta})$ is the rate of reaction $j$, which depends on the coverages of all species, and $n_{j, i}$ is the stoichiometric coefficient of species $i$ in reaction $j$. Microkinetic models often have rate constants that differ by many orders of magnitude, which makes the system of ODEs stiff. In this work, a method based on backward differentiation formulas within the VODE solver in $\mathrm{SciPy}^{42}$ has been used to numerically integrate the system of ODEs until the steady state is reached.

The rate constants $k$ for the surface reactions are calculated through transition-state theory ${ }^{43}$

$$
k=\frac{k_{\mathrm{B}} T}{h} \exp \left(\frac{\Delta S^{\#}}{k_{\mathrm{B}}}\right) \exp \left(\frac{-\Delta E^{\#}}{k_{\mathrm{B}} T}\right)=A_{\mathrm{f}} \exp \left(\frac{-\Delta E^{\#}}{k_{\mathrm{B}} T}\right)
$$

where $\Delta S^{\#}$ and $\Delta E^{\#}$ are the entropy and electronic energy differences between the transition state and the reactant, respectively. The entropies for the adsorbed species are calculated within the harmonic approximation, where the translations and rotations are treated as frustrated vibrations. ${ }^{44}$ $A_{\mathrm{f}}$ defines the pre-exponential factor for the forward reaction. The rate constants for the (non-activated) adsorption reactions are calculated according to collision theory

$$
k_{\mathrm{ads}}=\frac{P_{x} s_{0} a_{\text {site }}}{\sqrt{2 \pi m k_{\mathrm{B}} T}}=P_{x} A_{\mathrm{f}}
$$

where $P_{x}$ is the partial pressure of $x, s_{0}$ is the sticking coefficient at zero coverage, $a_{\text {site }}$ is the area of an adsorbed site, and $m$ is the mass of the molecule. $s_{0}$ is assumed to be unity for all cases. Thermodynamic consistency is enforced in the model by calculating the reverse rate constants from the equilibrium constants for all steps.
For the interactions between the adsorbed species, it is found that the majority of the interactions is repulsive with the exception of the $\mathrm{OH}-\mathrm{OH}$ interaction. We have included $\mathrm{O}-\mathrm{O}$ and $\mathrm{OH}-\mathrm{OH}$ interactions following ref 45 . The $\mathrm{H}-\mathrm{H}$ interactions are modeled in a linear fashion, as seen in the Supporting Information. The interactions between adsorbed $\mathrm{O}_{2}$ molecules are found to be small and, therefore, neglected in the model.

\section{RESULTS}

The direct synthesis of $\mathrm{H}_{2} \mathrm{O}_{2}$ from $\mathrm{H}_{2}$ and $\mathrm{O}_{2}$ proceeds over $\mathrm{Pd}$ catalysts at low temperatures $(275-315 \mathrm{~K})$ and reactant pressures normally in the range of $0.5-10 \mathrm{MPa} \mathrm{H}_{2}$ and $0.5-10$ $\mathrm{MPa} \mathrm{O}_{2} \cdot{ }^{4,14}$ At these pressures and temperatures, exposure of Pd to only $\mathrm{H}_{2}$ would result in the formation of palladium hydride ( $\alpha$ - or $\beta$-phase). ${ }^{34,46,47}$ Similarly, the exposure of Pd to $\mathrm{O}_{2}$ at these temperatures results initially to adsorbed oxygen and thereafter a two-dimensional surface oxide. ${ }^{48,49}$ Formation of bulk oxide requires for kinetic reasons higher temperatures. ${ }^{48}$ During $\mathrm{H}_{2} \mathrm{O}_{2}$ formation, $\mathrm{Pd}$ is exposed to both $\mathrm{H}_{2}$ and $\mathrm{O}_{2}$, which implies that it is important to investigate the stable surface structure with the relevant gas mixture.

State of the Catalyst. The stability of the calculated surface structures in equilibrium with gas-phase $\mathrm{H}_{2}$ and $\mathrm{O}_{2}$ is compared by evaluating the Gibbs free energy. Here, we have considered clean $\mathrm{Pd}(111)$, a $p(3 \times 3)$ overlayer of atomic oxygen on $\mathrm{Pd}(111), \mathrm{Pd}_{5} \mathrm{O}_{4}$ surface oxide ${ }^{48}$ on $\mathrm{Pd}(111)$, the PdO bulk, a $p(3 \times 3)$ overlayer of atomic hydrogen on $\operatorname{Pd}(111)$, and a $p(3 \times 3) \beta$-phase palladium hydride $(111)$ $\left[\mathrm{PdH}_{0.7}(111)\right]$. The considered structures focus on the state of the catalyst, being a metal, an oxide, or a hydride. The actual surface coverages, which are determined by both thermodynamics and reaction kinetics, are obtained by mean-field kinetic modeling as described below.

The stable phases at the corresponding $\mathrm{H}_{2}$ and $\mathrm{O}_{2}$ chemical potentials are shown in Figure 2. The clean $\mathrm{Pd}(111)$ surface is the stable phase when the $\mathrm{H}_{2}$ and $\mathrm{O}_{2}$ chemical potentials are low. If the $\mathrm{H}_{2}$ chemical potential is kept low and $\mathrm{O}_{2}$ chemical potential increases (along the $y$-axis) to oxygen-rich conditions, first a $p(3 \times 3)$ overlayer appears on the $\mathrm{Pd}(111)$ surface, then a $\mathrm{Pd}_{5} \mathrm{O}_{4}$ surface oxide, and finally the PdO bulk oxide. The structure of the surface oxide has been determined by in situ surface X-ray diffraction and core-level spectroscopy measurements. ${ }^{48}$ If the $\mathrm{O}_{2}$ chemical potential is kept low and the $\mathrm{H}_{2}$ chemical potential gradually increases (along the $x$-axis), a completely $\mathrm{H}$-covered $\operatorname{Pd}(111)$ surface is first formed and, thereafter, the $\beta$-phase palladium hydride $\left(\mathrm{PdH}_{0.7}\right)$. This is in good agreement with experimental results ${ }^{34,47}$ (at low temperatures, $\mathrm{Pd}$ goes directly between the metallic phase and $\beta$-phase $\left.{ }^{50}\right)$. The adsorption energy for hydrogen in the bulk is significantly lower than the adsorption energy on the surface, ${ }^{35}$ which implies that hydrogen will first occupy adsorption sites on the surface and only occupy bulk sites once a full surface coverage is obtained.

The relevant operating conditions during $\mathrm{H}_{2} \mathrm{O}_{2}$ synthesis over $\mathrm{Pd}$ are indicated by the white square in Figure $2\left(P_{\mathrm{H}_{2}}, P_{\mathrm{O}_{2}}\right.$ $=0.5-10 \mathrm{MPa}$, and $T=275-315 \mathrm{~K})$. The region of the square is situated in the $\beta$-hydride phase close to the boundary to the $\mathrm{Pd}_{5} \mathrm{O}_{4}$ surface oxide. Our results show that the $\beta$-hydride phase should be considered as the most abundant surface structure during $\mathrm{H}_{2} \mathrm{O}_{2}$ formation conditions, particularly when $\mathrm{H}_{2}$ is fed in excess. This finding is in accord with experimental X-ray 
absorption spectroscopy data, ${ }^{16}$ showing that the $\beta$-phase $\mathrm{PdH}$ is present for $\mathrm{H}_{2} / \mathrm{O}_{2}$ ratios $>1$.

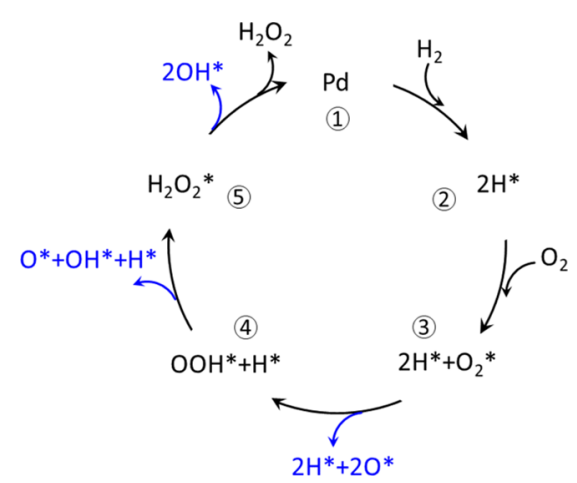

Figure 1. Schematic reaction cycle for direct formation of $\mathrm{H}_{2} \mathrm{O}_{2}$ from $\mathrm{H}_{2}$ and $\mathrm{O}_{2}$.

Reaction Paths over $\mathrm{Pd}(111)$ and $\mathrm{PdH}(111)$. The reaction paths for direct $\mathrm{H}_{2} \mathrm{O}_{2}$ formation from $\mathrm{H}_{2}$ and $\mathrm{O}_{2}$ on $\mathrm{Pd}(111)$ and $\beta-\mathrm{PdH}(111)$ are shown in Figures 3 and 4, respectively. Even though the $\beta$-hydride is the preferred phase during the reaction conditions, we consider the clean $\operatorname{Pd}(111)$ surface as a comparison. $\mathrm{On} \operatorname{Pd}(111), \mathrm{O}_{2}$ is first adsorbed in a molecular state over an fcc hollow site $(\mathrm{O} * \mathrm{O} *), \mathrm{H}_{2}$ is subsequently adsorbed and dissociated $\left(\mathrm{O}^{*} \mathrm{O}^{*}+2 \mathrm{H}^{*}\right)$. The dissociated atomic $\mathrm{H}$ atoms can react with $\mathrm{O}^{*} \mathrm{O} *$, forming an $\mathrm{O} * \mathrm{O} * \mathrm{H}$ species with a barrier of $0.54 \mathrm{eV}$. Thereafter, adsorbed hydrogen peroxide $(\mathrm{HO} * \mathrm{OH})$ can be formed with a high barrier of $0.86 \mathrm{eV}$. The surface hydrogen peroxide desorbs in the last step from the surface. The desorption energy is 0.60 $\mathrm{eV}$. However, there are a couple of possible side reactions along the potential energy landscape. $\mathrm{O}_{2}$ can dissociate with an activation energy of $0.63 \mathrm{eV}$, forming two oxygen atoms on the surface $\left(2 \mathrm{O}^{*}\right)$. Adsorbed $\mathrm{O}$ and $\mathrm{H}$ can react to form $\mathrm{O}^{*} \mathrm{H}$ with a barrier of $0.98 \mathrm{eV}$ (not shown in the figure). Another side reaction is the dissociation of the $\mathrm{O}^{*} \mathrm{O} * \mathrm{H}$ species to an $\mathrm{O}^{*}$ and an $\mathrm{O}^{*} \mathrm{H}$. This reaction has a small barrier of $0.11 \mathrm{eV}$. A water molecule can be formed by reaction between $\mathrm{O}^{*} \mathrm{H}$ and $\mathrm{H}^{*}$ with a barrier of $0.49 \mathrm{eV}$. The desorption energy of water is $0.45 \mathrm{eV}$. A third side reaction is the dissociation of surface $\mathrm{HO}^{*} \mathrm{OH}$ to two $\mathrm{O} * \mathrm{H}$ groups, which is exothermic and has a small barrier of $0.11 \mathrm{eV}$.

All our calculated energies for this reaction on $\operatorname{Pd}(111)$ are in good agreement with the previous studies. ${ }^{7,21}$ Note that water should mainly be formed by the reaction between two $\mathrm{OH}$ groups or hydrogenation of $\mathrm{HO}^{*} \mathrm{OH}$. The hydrogenation of $\mathrm{HO}^{*} \mathrm{OH}$ over $\mathrm{Pd}(111)$ is not considered as it is difficult to form $\mathrm{HO}^{*} \mathrm{OH}$ over $\mathrm{Pd}(111)$. The barrier for direct $\mathrm{O}_{2}$ dissociation over $\mathrm{Pd}(111)$ is high enough to hinder direct dissociation into $2 \mathrm{O}^{*}$ below room temperature. Moreover, the barrier for $\mathrm{OH}$ formation from atomic oxygen and hydrogen is high. This is consistent with the observation that $\mathrm{OH}$ groups are formed from $\mathrm{O}^{*}$ and $\mathrm{H}^{*}$ at step sites. ${ }^{51}$

Turning to the reaction paths on $\beta-\mathrm{PdH}(111)$ (Figure 4), the reaction landscape is more complicated than on clean $\operatorname{Pd}(111)$ due to the high coverage of the surface hydrogen and the existence of the bulk hydrogen. $\mathrm{H}_{2}$ is first dissociated on the surface, and the surface is thereafter fully covered by the hydrogen atoms. $\mathrm{O}_{2}$ is found to be physisorbed in a triplet state with an adsorption energy of $0.16 \mathrm{eV}$. The barrier to form a chemisorbed molecule in the singlet state is $0.61 \mathrm{eV}$. The direct dissociation of $\mathrm{O}_{2}$ has a large barrier of $1.12 \mathrm{eV}$. With chemisorbed $\mathrm{O}_{2}$, there are two paths to form $\mathrm{OOH}$ species. One is to form $\mathrm{HO}^{*} \mathrm{O}$ with one bond to the surface, which has a barrier of $0.22 \mathrm{eV}$. The other species $(\mathrm{O} * \mathrm{O} * \mathrm{H})$ has two bonds to the surface and is formed with a lower barrier of 0.12

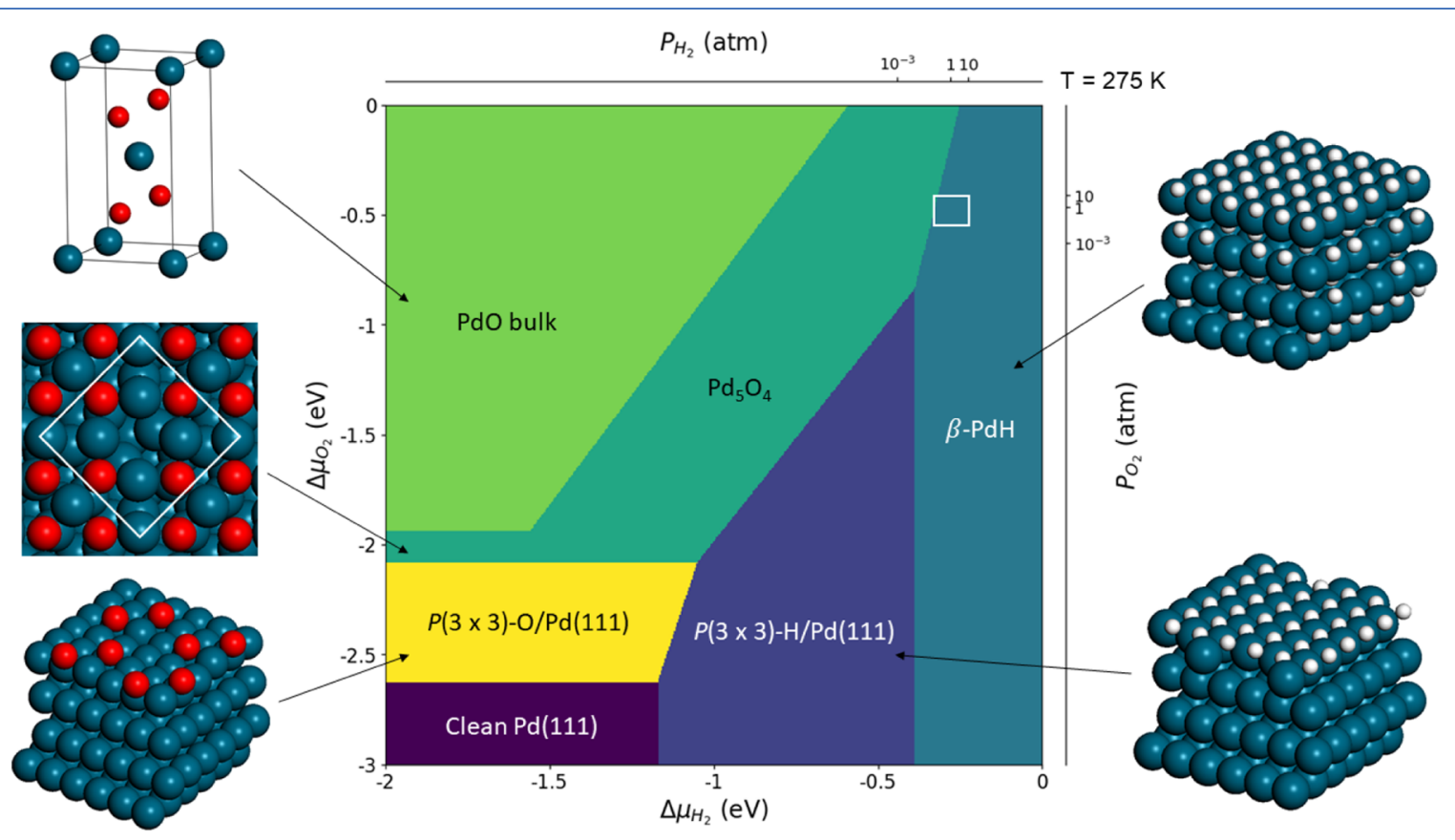

Figure 2. Surface phase diagram of $\mathrm{Pd}(111)$ in constrained thermodynamic equilibrium with gas-phase $\mathrm{H}_{2}$ and $\mathrm{O}_{2}$. The phase diagram is given with respect to the chemical potentials of $\mathrm{H}_{2}$ and $\mathrm{O}_{2}$. The corresponding $\mathrm{H}_{2}\left(\mathrm{O}_{2}\right)$ pressure at $275 \mathrm{~K}$ is shown in the black bar at the top (right) of the axis. The white square in the phase diagram denotes the typical gas conditions of direct $\mathrm{H}_{2} \mathrm{O}_{2}$ formation $\left[P_{\mathrm{H}_{2}}, P_{\mathrm{O}_{2}}=0.5-10 \mathrm{MPa}, T=275-315 \mathrm{~K}\right.$; atom color codes: Pd (blue), O (red), and H (white)]. 


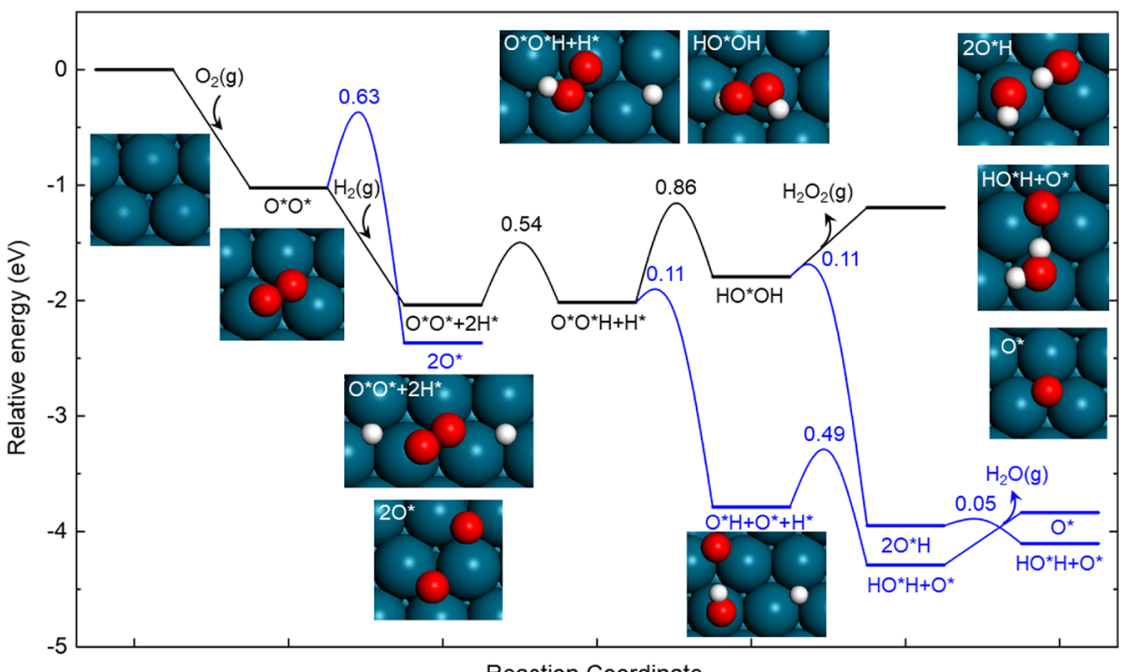

Reaction Coordinate

Figure 3. Potential energy landscape for direct $\mathrm{H}_{2} \mathrm{O}_{2}$ formation from $\mathrm{H}_{2}$ and $\mathrm{O}_{2}$ over $\mathrm{Pd}(111)$. The lines with the blue color represent the path toward the side reactions. All energies are zero-point-corrected. Atom color codes: Pd (blue), $\mathrm{O}$ (red), and $\mathrm{H}$ (white).

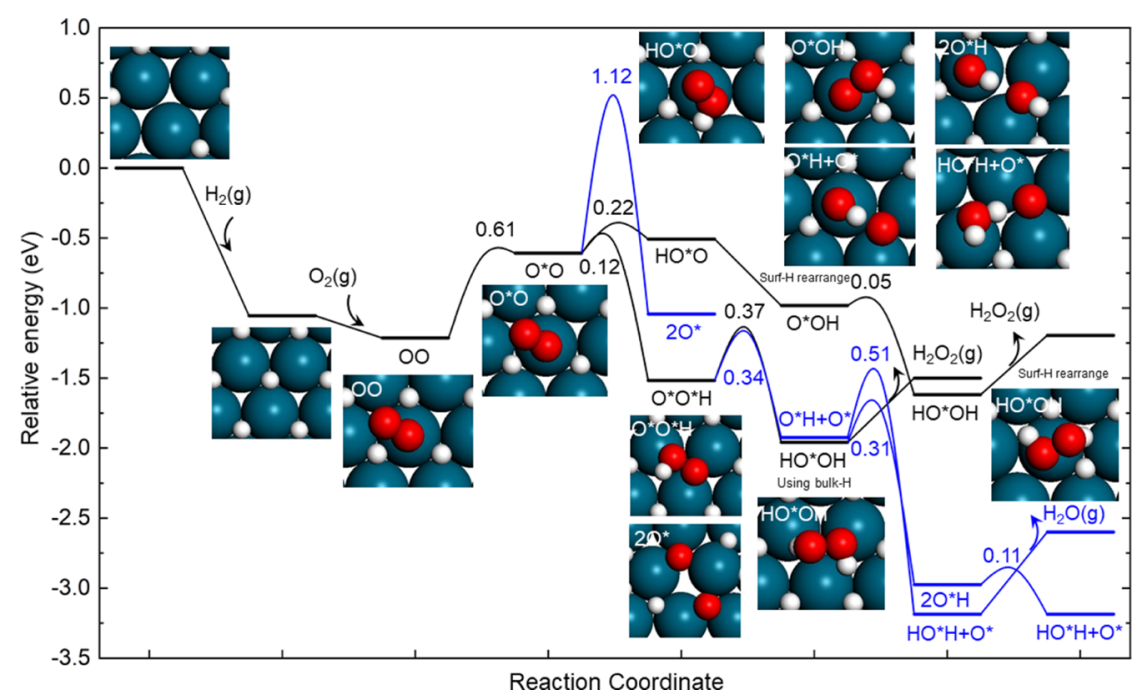

Figure 4. Potential energy landscape for direct $\mathrm{H}_{2} \mathrm{O}_{2}$ formation from $\mathrm{H}_{2}$ and $\mathrm{O}_{2}$ on $\beta-\mathrm{PdH}(111)$. The lines with the blue color represent the path toward the side reactions. Steps marked with surface- $\mathrm{H}$ rearrangement indicate that the surrounding hollow sites of the surface species are all covered by surface $\mathrm{H}$. All energies are zero-point-corrected. Atom color codes: Pd (blue), O (red), and H (white).

$\mathrm{eV}$. To continue the reaction with $\mathrm{HO}^{*} \mathrm{O}$, the species need to reorient and bind with the unhydrogenated oxygen atom to the surface $(\mathrm{O} * \mathrm{OH})$. This step is spontaneous with a full hydrogen coverage, which is maintained by either diffusion of $\mathrm{H}$ from the bulk or hydrogen adsorption. In the potential energy diagram, a local full coverage is kept by moving a surface hydrogen atom close to $\mathrm{HO}^{*} \mathrm{O}$. $\mathrm{HO}^{*} \mathrm{OH}$ is formed from $\mathrm{O} * \mathrm{OH}$ with a small barrier of $0.05 \mathrm{eV}$. The desorption energy of the adsorbed $\mathrm{HO}^{*} \mathrm{OH}$ is $0.38 \mathrm{eV}$. $\mathrm{HO}^{*} \mathrm{OH}$ can also be formed from $\mathrm{O}^{*} \mathrm{O} * \mathrm{H}$ by reaction with a subsurface hydrogen (e.g., bulk-dissolved $\mathrm{H}$ ) with a small barrier of 0.37 $\mathrm{eV}$. This is preferred with respect to a reaction with an adjacent surface hydrogen. The desorption energy of this $\mathrm{HO}^{*} \mathrm{OH}$ species is $0.38 \mathrm{eV}$.

The side reactions involve dissociation of the $\mathrm{O} * \mathrm{O} * \mathrm{H}$ species into an $\mathrm{O}^{*} \mathrm{H}$ group and an adsorbed $\mathrm{O}^{*}$, having a barrier of $0.34 \mathrm{eV}$. Another side reaction is the dissociation of $\mathrm{HO}^{*} \mathrm{OH}$, which proceeds with a barrier of $0.31 \mathrm{eV}$. This path is possible if there are free sites on the surface to accommodate
$2 \mathrm{O} * \mathrm{H}$. Water can be formed either with a barrier of $0.51 \mathrm{eV}$ from $\mathrm{O}^{*} \mathrm{H}$ and $\mathrm{H}^{*}$ or, alternatively, with a smaller barrier of 0.11 from $2 \mathrm{O}^{*} \mathrm{H}$. Note that the dissociation of $\mathrm{O}^{*} \mathrm{O} * \mathrm{H}$ and $\mathrm{HO}^{*} \mathrm{OH}$ requires higher barriers on the hydride $\mathrm{PdH}(111)$ than on the clean $\operatorname{Pd}(111)$ surface. This indicates that the presence of surface $\mathrm{H}$ should increase the selectivity toward $\mathrm{H}_{2} \mathrm{O}_{2}$. However, the potential energy landscape in Figure 4 also shows that the $\mathrm{O}_{2}$ adsorption step is endothermic, making $\mathrm{H}_{2} \mathrm{O}_{2}$ formation a very slow process.

We find that the interaction of $\mathrm{O}_{2}$ with $\mathrm{Pd}(111)$ and $\beta$ $\mathrm{PdH}(111)$ is significantly different. $\mathrm{O}_{2}$ binds to $\mathrm{Pd}(111)$ by $-1.02 \mathrm{eV}$, whereas the reaction is endothermic on $\beta$ $\mathrm{PdH}(111)$. There are two main reasons for the difference. One is the change in $\mathrm{Pd}$ electronic structure upon hydride formed. The densities of states of $\mathrm{Pd}, \mathrm{PdH}_{0.7}$, and $\mathrm{PdH}$ bulk are reported in the Supporting Information. The width of the dband is reduced and shifted to lower energies as the hydride is formed. Moreover, d-states are depleted from the Fermi level. These are changes that reduce the interaction with $\mathrm{O}_{2}{ }^{52}$ In 

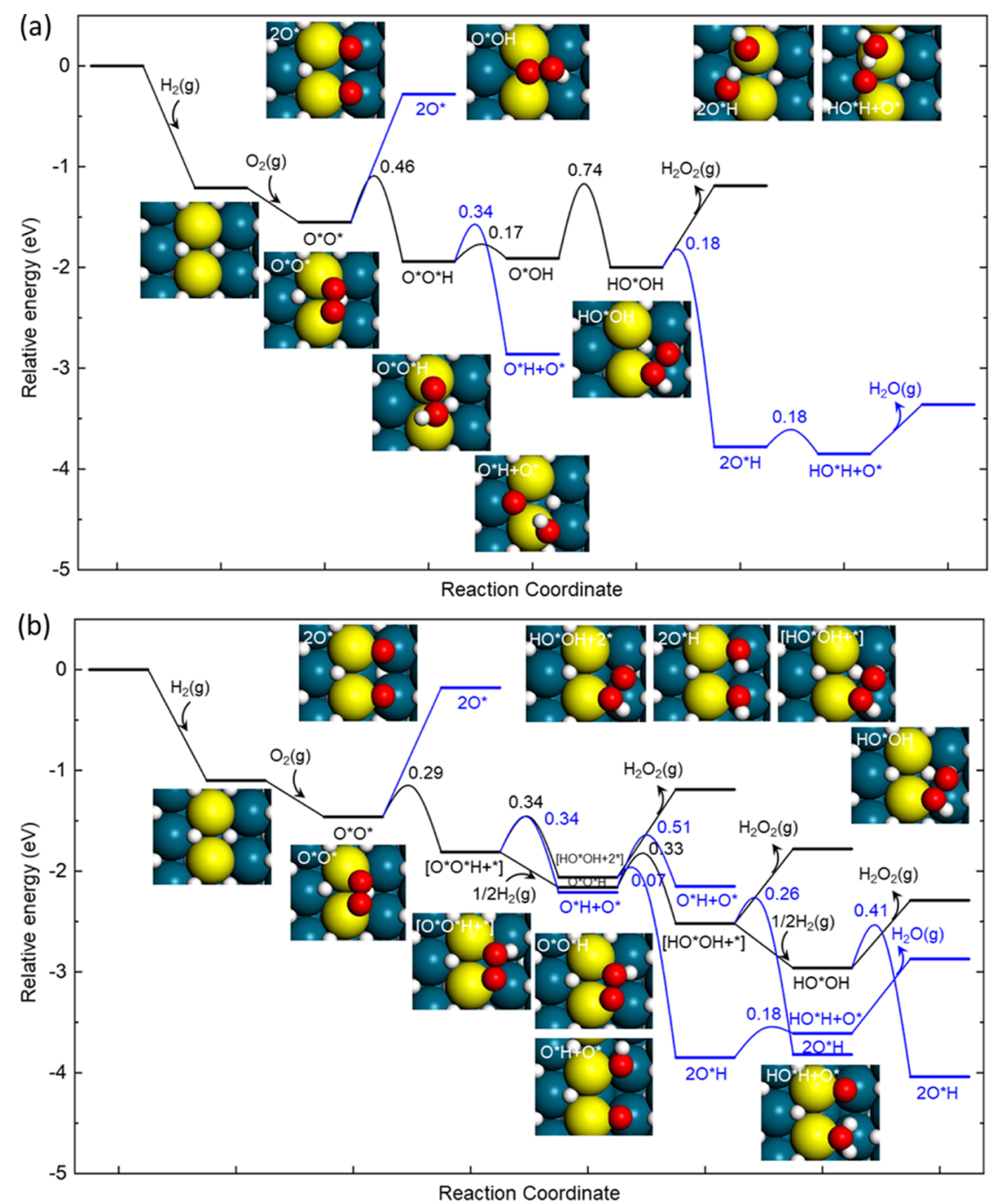

Figure 5. Potential energy landscape for direct $\mathrm{H}_{2} \mathrm{O}_{2}$ formation from $\mathrm{H}_{2}$ and $\mathrm{O}_{2}$ on $\beta$ - $\mathrm{PdH}(211)$. Two types of adsorbed $\mathrm{H}$ may take part in the reactions: (a) $\mathrm{H}$ on the (111) microfacet and (b) $\mathrm{H}$ on the (100) microfacet. The lines with the blue color represent the path toward the side reactions. All energies are zero-point-corrected. Pd atoms at the step edge are highlighted with the yellow color. Atom color codes: Pd (blue), O (red), and $\mathrm{H}$ (white).

addition, the $\mathrm{H}$ is slightly negatively charged in the hydride, which results in a repulsion to $\mathrm{O}_{2}$ upon adsorption.

Reaction Paths over $\mathrm{PdH}(211)$. Direct synthesis of $\mathrm{H}_{2} \mathrm{O}_{2}$ is typically performed over $\mathrm{Pd}$ nanoparticles, which have undercoordinated edge and corner sites. It is known that lowcoordinated sites may strongly influence the activity. ${ }^{53}$ To simulate the reactions on the edge sites of a $\mathrm{PdH}$ nanoparticle, here, $\mathrm{H}_{2} \mathrm{O}_{2}$ formation has been investigated on the stepped $\operatorname{PdH}(211)$ surface, as seen in Figure 5. Owing to the lowcoordinated $\mathrm{Pd}$ atoms on the edges, $\mathrm{O}_{2}$ adsorbs on this surface by $-0.35 \mathrm{eV}$. The dissociation of $\mathrm{O}^{*} \mathrm{O}^{*}$ on the stepped surface with a full coverage of hydrogen is strongly endothermic by $1.27 \mathrm{eV}$, which implies that direct dissociation is hindered under reaction conditions. After the adsorption of $\mathrm{O}_{2}$, there are two possible routes for $\mathrm{OOH}$ formation. One route uses the $\mathrm{H}^{*}$ from the (111) microfacet (Figure 5a), and the other uses the $\mathrm{H}$ from the (100) microfacet (Figure 5b).

Following the path in Figure 5a, O*O* $\mathrm{O}$ formation proceeds via a barrier of $0.46 \mathrm{eV}$. The subsequent formation of $\mathrm{HO}^{*} \mathrm{OH}$ involves two steps. First, $\mathrm{O} * \mathrm{O} * \mathrm{H}$ reorients with a barrier of $0.17 \mathrm{eV}$ to allow for a reaction with the second $\mathrm{H}^{*}$ on the (111) microfacet. Second, $\mathrm{HO}^{*} \mathrm{OH}$ is formed with a barrier of $0.74 \mathrm{eV}$. A side reaction is at this point dissociation of $\mathrm{O}^{*} \mathrm{O}^{*} \mathrm{H}$ into $\mathrm{O}^{*} \mathrm{H}$ and $\mathrm{O}^{*}$. The barrier for this reaction is $0.34 \mathrm{eV}$. Moreover, adsorbed $\mathrm{HO}^{*} \mathrm{OH}$ is found to dissociate easily with a barrier of $0.18 \mathrm{eV}$. $\mathrm{HO}^{*} \mathrm{H}$ can be formed from two $\mathrm{O} * \mathrm{H}$ groups, a process that has a barrier of $0.18 \mathrm{eV}$. The desorption of $\mathrm{HO}^{*} \mathrm{OH}$ and $\mathrm{HO}^{*} \mathrm{H}$ from the edges is less facile than the desorption on the $\operatorname{Pd}(111)$ surface due to their stronger binding energies.

Turning to the path in Figure $5 \mathrm{~b}$, the $\mathrm{O} * \mathrm{O} * \mathrm{H}$ formation from $\mathrm{O}^{*} \mathrm{O}^{*}$ and the $\mathrm{H}^{*}$ on the $(100)$ microfacet requires a smaller barrier $(0.29 \mathrm{eV})$ than the formation using $\mathrm{H}$ on the (111) microfacet $(0.46 \mathrm{eV})$. The more facile transport of $\mathrm{H}$ from the (100) microfacet can be explained by a $0.1 \mathrm{eV}$ weaker bond to the surface. After the formation of $\mathrm{O}^{*} \mathrm{O} * \mathrm{H}$, there are three possibilities for the following reactions: (i) $\mathrm{HO}^{*} \mathrm{OH}$ can be formed via a barrier of $0.34 \mathrm{eV}$. $\mathrm{HO} * \mathrm{OH}$ can either desorb by $0.86 \mathrm{eV}$ or dissociate into two $\mathrm{O}^{*} \mathrm{H}$ groups via a small $(0.07$ $\mathrm{eV})$ barrier. The two $\mathrm{O} * \mathrm{H}$ groups can react with each other, forming a $\mathrm{HO}^{*} \mathrm{H}$ species by a barrier of $0.18 \mathrm{eV}$. The desorption of $\mathrm{HO}^{*} \mathrm{H}$ is endothermic by $0.74 \mathrm{eV}$. (ii) $\mathrm{O} * \mathrm{O} * \mathrm{H}$ can dissociate to $\mathrm{O} * \mathrm{H}+\mathrm{O} *$ with a barrier of $0.34 \mathrm{eV}$. (iii) As empty sites are formed upon $\mathrm{O}^{*} \mathrm{O} * \mathrm{H}$ formation, it is feasible 
Table 1. Considered Elementary Reaction Steps on $\operatorname{PdH}(211)$ with $H$ Transferred from the (100) Microfacet ${ }^{a}$

\begin{tabular}{|c|c|c|c|c|c|}
\hline no. & reaction equation & $E_{\mathrm{f}}(\mathrm{eV})$ & $A_{\mathrm{f}}$ & $E_{\mathrm{b}}(\mathrm{eV})$ & $A_{\mathrm{b}}$ \\
\hline (1) & $\mathrm{H}_{2}(\mathrm{~g})+2^{*} \leftrightarrow 2 \mathrm{H}^{*}$ & 0.00 & $1.06 \times 10^{3}$ & 1.03 & $8.84 \times 10^{7}$ \\
\hline (2) & $\mathrm{O}_{2}(\mathrm{~g})+2 *($ edge $) \leftrightarrow \mathrm{O} * \mathrm{O} *($ edge $)$ & 0.00 & $2.67 \times 10^{3}$ & 0.36 & $1.30 \times 10^{10}$ \\
\hline (3) & $\mathrm{O} * \mathrm{O} *($ edge $)+\mathrm{H}^{*} \leftrightarrow[\mathrm{O} * \mathrm{O} * \mathrm{H}($ edge $)+*]$ & 0.29 & $2.77 \times 10^{12}$ & 0.65 & $1.90 \times 10^{12}$ \\
\hline (4) & $\mathrm{O}^{*} \mathrm{O} *($ edge $)+2^{*} \leftrightarrow 2 \mathrm{O}^{*}+2^{*}($ edge $)$ & 1.28 & $2.57 \times 10^{12}$ & 0.00 & $1.28 \times 10^{13}$ \\
\hline (5) & {$[\mathrm{O} * \mathrm{O} * \mathrm{H}(\text { edge })+*]_{\mathrm{str} 1}+\mathrm{H}^{*} \leftrightarrow\left[\mathrm{HO} * \mathrm{OH}(\text { edge })+2^{*}\right]_{\mathrm{str} 1}+*($ edge $)$} & 0.34 & $2.83 \times 10^{12}$ & 0.60 & $1.15 \times 10^{12}$ \\
\hline (6) & {$[\mathrm{O} * \mathrm{O} * \mathrm{H}(\text { edge })+*]_{\mathrm{strl}}+* \leftrightarrow \mathrm{O} * \mathrm{H}+\mathrm{O} *+2 *($ edge $)$} & 0.34 & $1.67 \times 10^{12}$ & 0.74 & $5.18 \times 10^{12}$ \\
\hline (7) & {$[\mathrm{O} * \mathrm{O} * \mathrm{H}(\text { edge })+*]_{\mathrm{str} 1}+\mathrm{H}_{2}(\mathrm{~g})+* \leftrightarrow[\mathrm{O} * \mathrm{O} * \mathrm{H}(\text { edge })]_{\mathrm{str} 2}+2 \mathrm{H}^{*}$} & 0.00 & $1.06 \times 10^{3}$ & 0.70 & $2.91 \times 10^{5}$ \\
\hline$(8)$ & {$[\mathrm{HO} * \mathrm{OH}(\text { edge })+2 *]_{\text {str } 1} \leftrightarrow \mathrm{H}_{2} \mathrm{O}_{2}(\mathrm{~g})+2^{*}+*($ edge $)$} & 0.87 & $6.80 \times 10^{15}$ & 0.00 & $2.59 \times 10^{2}$ \\
\hline$\left(8^{\prime}\right)$ & {$[\mathrm{HO} * \mathrm{OH}(\text { edge })+2 *]_{\mathrm{str} 1} \leftrightarrow \mathrm{H}_{2} \mathrm{O}_{2}(\mathrm{l})+2 *+*($ edge $)$} & 0.42 & $5.65 \times 10^{6}$ & 0.00 & $2.59 \times 10^{2}$ \\
\hline (9) & {$[\mathrm{HO} * \mathrm{OH}(\text { edge })+2 *]_{\text {str } 1} \leftrightarrow \mathrm{O} * \mathrm{H}+\mathrm{O} * \mathrm{H}+*($ edge $)$} & 0.07 & $2.16 \times 10^{12}$ & 1.86 & $1.11 \times 10^{13}$ \\
\hline (10) & {$[\mathrm{O} * \mathrm{O} * \mathrm{H}(\text { edge })]_{\mathrm{str} 2}+\mathrm{H}^{*} \leftrightarrow[\mathrm{HO} * \mathrm{OH}(\text { edge })+*]_{\mathrm{str} 2}+*($ edge $)$} & 0.33 & $2.95 \times 10^{12}$ & 0.69 & $1.33 \times 10^{12}$ \\
\hline (11) & {$[\mathrm{HO} * \mathrm{OH}(\text { edge })+*]_{\mathrm{str} 2} \leftrightarrow \mathrm{H}_{2} \mathrm{O}_{2}(\mathrm{~g})+*+*($ edge $)$} & 0.74 & $6.80 \times 10^{15}$ & 0.00 & $2.59 \times 10^{2}$ \\
\hline$\left(11^{\prime}\right)$ & {$[\mathrm{HO} * \mathrm{OH}(\text { edge })+*]_{\mathrm{str} 2} \leftrightarrow \mathrm{H}_{2} \mathrm{O}_{2}(\mathrm{l})+*+*($ edge $)$} & 0.29 & $5.65 \times 10^{6}$ & 0.00 & $2.59 \times 10^{2}$ \\
\hline$(12)$ & {$[\mathrm{O} * \mathrm{O} * \mathrm{H}(\text { edge })]_{\mathrm{str} 2}+2 * \leftrightarrow \mathrm{O} * \mathrm{H}+\mathrm{O} *+2 *($ edge $)$} & 0.51 & $3.78 \times 10^{12}$ & 0.50 & $1.69 \times 10^{13}$ \\
\hline (13) & {$[\mathrm{HO} * \mathrm{OH}(\text { edge })+*]_{\mathrm{str} 2}+\mathrm{H}_{2}(\mathrm{~g})+* \leftrightarrow[\mathrm{HO} * \mathrm{OH}(\text { edge })]_{\mathrm{str} 3}+2 \mathrm{H}^{*}$} & 0.00 & $1.06 \times 10^{3}$ & 0.88 & $3.17 \times 10^{5}$ \\
\hline (14) & {$[\mathrm{HO} * \mathrm{OH}(\text { edge })]_{\mathrm{str} 3} \leftrightarrow \mathrm{H}_{2} \mathrm{O}_{2}(\mathrm{~g})+*($ edge $)$} & 0.67 & $7.34 \times 10^{15}$ & 0.00 & $2.59 \times 10^{2}$ \\
\hline$\left(14^{\prime}\right)$ & {$[\mathrm{HO} * \mathrm{OH}(\text { edge })]_{\mathrm{str} 3} \leftrightarrow \mathrm{H}_{2} \mathrm{O}_{2}(\mathrm{l})+*($ edge $)$} & 0.22 & $6.11 \times 10^{6}$ & 0.00 & $2.59 \times 10^{2}$ \\
\hline$(15)$ & {$[\mathrm{HO} * \mathrm{OH}(\text { edge })]_{\mathrm{str} 3}+2^{*} \leftrightarrow \mathrm{O} * \mathrm{H}+\mathrm{O} * \mathrm{H}+*($ edge $)$} & 0.41 & $2.41 \times 10^{12}$ & 1.49 & $1.63 \times 10^{13}$ \\
\hline (16) & $\mathrm{O} * \mathrm{H}+\mathrm{O}^{*} \mathrm{H}+*($ edge $) \leftrightarrow \mathrm{HO} * \mathrm{H}($ edge $)+\mathrm{O}^{*}+*$ & 0.18 & $4.10 \times 10^{12}$ & 0.04 & $1.79 \times 10^{12}$ \\
\hline (17) & $\mathrm{HO} * \mathrm{H}($ edge $) \leftrightarrow \mathrm{H}_{2} \mathrm{O}(\mathrm{g})+*($ edge $)$ & 0.74 & $1.36 \times 10^{15}$ & 0.00 & $3.56 \times 10^{2}$ \\
\hline$\left(17^{\prime}\right)$ & $\mathrm{HO} * \mathrm{H}($ edge $) \leftrightarrow \mathrm{H}_{2} \mathrm{O}(\mathrm{l})+*($ edge $)$ & 0.29 & $2.20 \times 10^{6}$ & 0.00 & $3.56 \times 10^{2}$ \\
\hline$(18)$ & $\mathrm{O}^{*}+\mathrm{H}^{*} \leftrightarrow \mathrm{O}^{*} \mathrm{H}+*$ & 0.69 & $4.25 \times 10^{12}$ & 1.19 & $2.58 \times 10^{12}$ \\
\hline (19) & $\mathrm{O}^{*} \mathrm{H}+\mathrm{H}^{*}+*($ edge $) \leftrightarrow \mathrm{HO}^{*} \mathrm{H}($ edge $)+2^{*}$ & 0.58 & $5.38 \times 10^{12}$ & 0.96 & $1.25 \times 10^{12}$ \\
\hline (20) & {$[\mathrm{HO} * \mathrm{OH}(\text { edge })+*]_{\mathrm{str} 2}+* \leftrightarrow \mathrm{O} * \mathrm{H}+\mathrm{O} * \mathrm{H}+*($ edge $)$} & 0.26 & $2.08 \times 10^{12}$ & 1.56 & $9.52 \times 10^{12}$ \\
\hline
\end{tabular}

${ }^{a_{T}}$ The forward $\left(E_{\mathrm{f}}\right)$ and backward $\left(E_{\mathrm{b}}\right)$ energy barriers are reported with zero-point corrections. The desorption steps with a prime denote the desorption into the liquid state. As the reaction network has different structures of $\mathrm{O} * \mathrm{O} * \mathrm{H}$ and $\mathrm{HO} * \mathrm{OH}$, we denote the different possibilities by $[\mathrm{O} * \mathrm{O} * \mathrm{H}(\text { edge })+*]_{\mathrm{str} 1},[\mathrm{O} * \mathrm{O} * \mathrm{H}(\text { edge })]_{\mathrm{str} 2},[\mathrm{HO} * \mathrm{OH}(\text { edge })+2 *]_{\mathrm{str} 1},[\mathrm{HO} * \mathrm{OH}(\text { edge })+*]_{\mathrm{str} 2}$, and $[\mathrm{HO} * \mathrm{OH}(\text { edge })]_{\mathrm{str} 3}$. The different structures are shown in the Supporting Information.

to fill this site either by $\mathrm{H}$ diffusion or by $\mathrm{H}_{2}$ adsorption, yielding a full coverage. In Figure $5 b$, the empty site is filled by $\mathrm{H}_{2}$ adsorption. The high coverage of $\mathrm{H}$ on the (100) microfacet makes the dissociation of $\mathrm{O} * \mathrm{O} * \mathrm{H}$ less facile than the formation of $\mathrm{HO}^{*} \mathrm{OH}$. The dissociation has a barrier of $0.51 \mathrm{eV}$, whereas $\mathrm{HO}^{*} \mathrm{OH}$ is formed by a barrier of $0.33 \mathrm{eV}$. The formation of $\mathrm{HO}^{*} \mathrm{OH}$ gives rise to an empty site, and the dissociation of $\mathrm{HO} * \mathrm{OH}$ to two $\mathrm{O}^{*} \mathrm{H}$ groups is associated with a barrier of $0.26 \mathrm{eV}$. Once $\mathrm{HO}^{*} \mathrm{OH}$ is formed, the full coverage can be maintained by yet another $\mathrm{H}_{2}$ adsorption step. The dissociation of $\mathrm{HO} * \mathrm{OH}$ to two $\mathrm{O} * \mathrm{H}$ groups on the edges with a high $\mathrm{H}$ coverage has a barrier of $0.41 \mathrm{eV}$. The barrier for the dissociation of $\mathrm{HO}^{*} \mathrm{OH}$ to two $\mathrm{O} * \mathrm{H}$ groups increases from 0.07 to $0.41 \mathrm{eV}$ with increasing surface $\mathrm{H}$ coverage. This shows that a high $\mathrm{H}$ coverage slows down the dissociation. Moreover, the desorption of $\mathrm{HO}^{*} \mathrm{OH}$ is endothermic by $0.67 \mathrm{eV}$. The full coverage of $\mathrm{H}$ reduces the desorption energy of $\mathrm{HO} * \mathrm{OH}$ on the edges. The desorption energies with one or two hydrogen vacancies close to $\mathrm{HO} * \mathrm{OH}$ are calculated to be 0.74 and 0.86 $\mathrm{eV}$, respectively.

Microkinetic Analysis. The relevance of the proposed reaction landscape can be verified by performing a microkinetic analysis with the calculated kinetic parameters. In the microkinetic simulations, the partial pressures of $\mathrm{H}_{2}$ and $\mathrm{O}_{2}$ are chosen to be $1 \mathrm{~atm}$. The $\mathrm{H}_{2} \mathrm{O}_{2}$ and $\mathrm{H}_{2} \mathrm{O}$ pressures are set to close to 0 . The temperatures for the simulations are ramped from 275 to $315 \mathrm{~K}$, which is within the experimental regime. ${ }^{4}$

The microkinetic simulations for the direct $\mathrm{H}_{2} \mathrm{O}_{2}$ formation provide information on both the rate of product formation and the coverages of the surface species and have been performed for the potential energy surfaces for $\mathrm{PdH}(111)$ (Figure 4) and
$\mathrm{PdH}(211)$ (Figure 5), respectively. We find that no $\mathrm{H}_{2} \mathrm{O}_{2}$ is formed over $\mathrm{PdH}(111)$ in the studied temperature interval. The kinetic bottleneck is the adsorption of $\mathrm{O}_{2}$. The results for $\mathrm{PdH}(111)$ are reported in the Supporting Information. For the $\mathrm{PdH}(211)$ surface, the use of $\mathrm{H}$ atoms from the (111) microfacet involves a high barrier, which prevent facile $\mathrm{H}_{2} \mathrm{O}_{2}$ formation (see the Supporting Information). Here, we concentrate on the results for the $\operatorname{PdH}(211)$ surface where $\mathrm{H}$ atoms are transferred from the (100) microfacet. The reaction barriers and pre-exponential factors (at $275 \mathrm{~K}$ ) for forward and backward reactions between the adsorbed $\mathrm{O}_{2}$ and $\mathrm{H}$ on the (100) microfacet are listed in Table 1. The parameters for $\mathrm{H}_{2} \mathrm{O}_{2}$ and $\mathrm{H}_{2} \mathrm{O}$ desorption have been adjusted to account for the fact that the desorption is to the liquid phase. In particular, experimental heats of vaporization and liquid-state entropies are used (see the Supporting Information). ${ }^{38}$

The pre-exponential factors (at $275 \mathrm{~K}$ ) for forward and backward reactions are denoted by $A_{\mathrm{f}}$ and $A_{\mathrm{b}}$, respectively. The pre-exponential factors for surface reactions and desorption events are given in $(1 / \mathrm{s})$. The pre-exponential factors for adsorption are given in $\left(\mathrm{Pa}^{-1} \mathrm{~s}^{-1}\right)$. Species with (edge) denote the adsorption sites on the edges.

The turnover frequency (TOF) is given by the rate of the formation of the product. Figure 6 shows the TOF of the formation of $\mathrm{H}_{2} \mathrm{O}_{2}$ and $\mathrm{H}_{2} \mathrm{O}$ as a function of temperature. We find that the TOF for the formation of $\mathrm{H}_{2} \mathrm{O}_{2}$ is lower than the TOF for $\mathrm{H}_{2} \mathrm{O}$ formation in the entire temperature interval. $\mathrm{H}_{2} \mathrm{O}_{2}$ formation has a maximum at $295 \mathrm{~K}$, whereas the $\mathrm{H}_{2} \mathrm{O}$ rate monotonically increases with temperature. The reason for the decrease in TOF for $\mathrm{H}_{2} \mathrm{O}_{2}$ is the onset of the $\mathrm{H}_{2} \mathrm{O}_{2}$ 


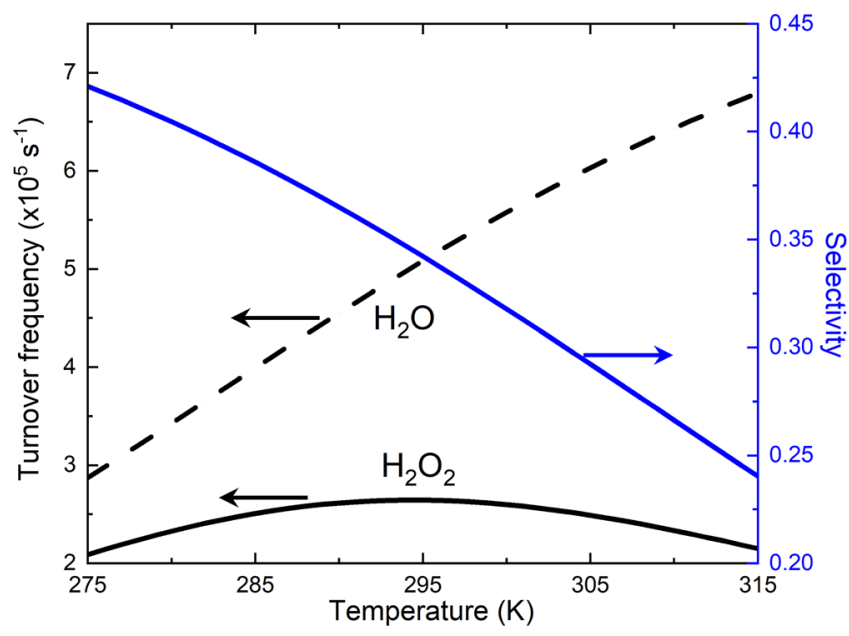

Figure 6. TOF for $\mathrm{H}_{2} \mathrm{O}_{2}$ and $\mathrm{H}_{2} \mathrm{O}$ formation on the stepped surface $\mathrm{PdH}(211)$ as a function of temperature. The selectivity toward the formation of $\mathrm{H}_{2} \mathrm{O}_{2}$ is given in blue. The pressures of $\mathrm{H}_{2}$ and $\mathrm{O}_{2}$ are both $1 \mathrm{~atm}$.

decomposition into $\mathrm{OH}$ groups. The TOF of $\mathrm{H}_{2} \mathrm{O}_{2}$ formation shows a moderate dependence on temperature in the range of 278-288 K, which agrees with experiments. ${ }^{14}$ Moreover, the decrease in $\mathrm{H}_{2} \mathrm{O}_{2}$ formation at higher temperatures (above $\sim 305 \mathrm{~K}$ ) due to $\mathrm{HO}^{*} \mathrm{OH}$ decomposition is also in agreement with experiments. ${ }^{17,54}$

The selectivity toward $\mathrm{H}_{2} \mathrm{O}_{2}$ formation $\left(\mathrm{S}_{\mathrm{H}_{2} \mathrm{O}_{2}}\right)$ is defined as

$$
S_{\mathrm{H}_{2} \mathrm{O}_{2}}=\frac{\mathrm{TOF}_{\mathrm{H}_{2} \mathrm{O}_{2}}}{\mathrm{TOF}_{\mathrm{H}_{2} \mathrm{O}_{2}}+\mathrm{TOF}_{\mathrm{H}_{2} \mathrm{O}}}
$$

where $\mathrm{TOF}_{\mathrm{H}_{2} \mathrm{O}_{2}}$ and $\mathrm{TOF}_{\mathrm{H}_{2} \mathrm{O}}$ are the TOFs for $\mathrm{H}_{2} \mathrm{O}_{2}$ and $\mathrm{H}_{2} \mathrm{O}$ formation, respectively. The corresponding selectivity at each temperature is given in Figure 6. The selectivity toward $\mathrm{H}_{2} \mathrm{O}_{2}$ formation decreases with increasing temperature. This implies that direct $\mathrm{H}_{2} \mathrm{O}_{2}$ formation should be performed at low temperatures to reach high selectivity. This finding is consistent with the experimental data., 14,54 The reaction order in $\mathrm{H}_{2}$ is calculated to increase from 0.3 to 0.7 as the temperature is increased. The reaction order in $\mathrm{O}_{2}$ is calculated to be negative (about -0.2) in the studied temperature interval. The reaction order in $\mathrm{H}_{2}$ has been measured to be either $0.5^{10}$ or $1.0 .^{14}$ The reaction order in $\mathrm{O}_{2}$ was in ref 10 measured to be slightly negative. We have also performed a degree of rate control (DRC) ${ }^{55}$ analysis (Figure S7 in the Supporting Information). $\mathrm{H}_{2}$ adsorption and $\mathrm{HO}^{*} \mathrm{OH}$ formation from $\mathrm{O}^{*} \mathrm{O} * \mathrm{H}$ have a positive $\mathrm{DRC}$ as well as $\mathrm{H}_{2} \mathrm{O}$ desorption. Instead, $\mathrm{HO}^{*} \mathrm{OH}$ dissociation into $2 \mathrm{O} * \mathrm{H}$ has a negative DRC.

\section{DISCUSSION}

In the results, we identify three key findings important for the mechanism of direct $\mathrm{H}_{2} \mathrm{O}_{2}$ synthesis: (i) the Pd catalyst exists in its hydride form under typical direct synthesis conditions; (ii) $\mathrm{H}_{2} \mathrm{O}_{2}$ selectivity is significantly improved on the hydride thanks to a combination of facile $\mathrm{H}$ addition and suppression of water formation; and (iii) $\mathrm{H}_{2} \mathrm{O}_{2}$ synthesis rates are much higher on edge sites than on Pd particle terraces. Below, we elaborate on these conclusions and discuss them in the context of prior experimental work.
Recent X-ray absorption experiments show that under $\mathrm{H}_{2}$ / $\mathrm{O}_{2}$ ratios larger than 1 , hydride is present under reaction conditions and that a phase transition to an oxide-terminated metal surface takes place as the $\mathrm{H}_{2} / \mathrm{O}_{2}$ ratio is lowered. ${ }^{15}$ This agrees with the presented phase diagram. Experimentally, the oxide surface also shows some selectivity toward $\mathrm{H}_{2} \mathrm{O}_{2}$ synthesis. ${ }^{16}$ The mechanism for the activity of the oxide surface could be related to the mechanism for the hydride surface, for example, a completely oxidized surface disfavors $\mathrm{O}-\mathrm{O}$ bond rupture.

Hydrides have previously been found to be associated with higher selectivity for direct $\mathrm{H}_{2} \mathrm{O}_{2}$ synthesis. ${ }^{4,6}$ The results reported here provide insights into the reasons for these observations. One possible explanation for the importance of the hydride is associated with a high $\mathrm{H}$ coverage on the surface, which prevents the side reactions and facilitates the desorption of $\mathrm{HO}^{*} \mathrm{OH}$, as shown in the reaction landscapes. Compared with the potential energy landscape on clean $\operatorname{Pd}(111)$, the coverage of the surface hydrogen plays an important role to prevent the side reactions on $\beta-\mathrm{PdH}(111)$. With the full coverage of hydrogen on $\beta-\mathrm{PdH}(111), \mathrm{O}_{2}$ prefers to be adsorbed as $\mathrm{O} * \mathrm{O}$ species and the dissociation is kinetically hindered by a higher activation energy of $1.12 \mathrm{eV}$. This kind of site blocking created by surface $\mathrm{H}$ atoms would also hypothetically be observed for other types of surface adsorbates. Long-chain ligands, such as alkanethiols ${ }^{56-58}$ and alkyl ammonium phosphates, ${ }^{7}$ have been found to improve $\mathrm{H}_{2} \mathrm{O}_{2}$ yields, likely by suppressing the undesired $\mathrm{O}-\mathrm{O}$ bond breaking. In addition to inhibiting $\mathrm{O}-\mathrm{O}$ dissociation reactions, the presence of a hydride phase promotes $\mathrm{H}$ addition reactions. Keeping the molecular oxygen $\left(\mathrm{O}^{*} \mathrm{O}\right)$ on the surface promotes the formation of surface $\mathrm{OOH}$ species. The barriers for $\mathrm{OOH}$ formation are lower than those on clean $\mathrm{Pd}(111)$. In addition, having a high coverage of surface hydrogen also makes the formation of $\mathrm{HO}^{*} \mathrm{OH}$ from $\mathrm{HO}^{*} \mathrm{O}$ more facile than on clean $\mathrm{Pd}(111)$; the barrier is calculated to be only $0.05 \mathrm{eV}$ on the hydride. The spontaneous desorption of $\mathrm{HO} * \mathrm{OH}$ from a surface with high $\mathrm{H}$ coverage implies that surface hydrogen also prevents the dissociation of $\mathrm{HO}^{*} \mathrm{OH}$. Moreover, the formation of $\mathrm{HO} * \mathrm{OH}$ from $\mathrm{O} * \mathrm{O} * \mathrm{H}$ species by using subsurface hydrogen shows that bulk-dissolved hydrogen in Pd can promote the direct formation of $\mathrm{H}_{2} \mathrm{O}_{2}$.

The importance of the reactant pressure for the selectivity of $\mathrm{H}_{2} \mathrm{O}_{2}$ production was first found experimentally by Lunsford. ${ }^{59}$ Recently, Wilson and Flaherty ${ }^{10}$ observed that the rate of $\mathrm{H}_{2} \mathrm{O}_{2}$ production increases dramatically with the $\mathrm{H}_{2}$ pressure keeping the $\mathrm{O}_{2}$ pressure fixed. On the contrary, increasing the $\mathrm{O}_{2}$ pressure with a fixed $\mathrm{H}_{2}$ pressure did not result in a changed rate for $\mathrm{H}_{2} \mathrm{O}_{2}$ formation. This is an indication that the state of the catalyst, being in either a hydride state or an oxide state, is critical for the selectivity to $\mathrm{H}_{2} \mathrm{O}_{2}$.

Even though the barriers for $\mathrm{OOH}$ and $\mathrm{HOOH}$ formation are low on the $\mathrm{PdH}(111)$ surface, the endothermic adsorption of $\mathrm{O}_{2}$ on $\mathrm{PdH}(111)$ leads to a very low predicted reaction rate. Thus, hydrogen-covered (111) terraces of large $\mathrm{Pd}$ nanoparticles should, in principle, be inert for direct $\mathrm{H}_{2} \mathrm{O}_{2}$ production. Instead, the undercoordinated atoms at the edge of a stepped surface provide sites for $\mathrm{O}_{2}$ adsorption and facile $\mathrm{H}_{2} \mathrm{O}_{2}$ formation. Our finding highlights the importance of undercoordinated sites in typical Pd nanoparticles for the direct synthesis of $\mathrm{H}_{2} \mathrm{O}_{2}$. This hypothesis appears to accord with recent observations of enhanced $\mathrm{H}_{2} \mathrm{O}_{2}$ direct synthesis for catalysts with $\mathrm{Pd}$ clusters below $2 \mathrm{~nm}^{11}$ as well as earlier 
reports of an enhanced yield for palladium nanoparticles with a high number undercoordinated sites. ${ }^{5}$

We note that it has been suggested that $\mathrm{H}_{2} \mathrm{O}_{2}$ can be formed via sequential protonation of adsorbed $\mathrm{O}_{2}$ and $\mathrm{OOH}$ from $\mathrm{H}^{+}$ in the solution. ${ }^{10}$ In ref 10 , it was found that the $\mathrm{H}_{2} \mathrm{O}_{2}$ formation rates require $\mathrm{H}^{+}$in the solution and that the rate increased with addition of $\mathrm{H}^{+}$donors (e.g., $\mathrm{H}_{2} \mathrm{SO}_{4}, \mathrm{HCl}$, or $\mathrm{H}_{2} \mathrm{CO}_{3}$ ), whereas rates for $\mathrm{H}_{2} \mathrm{O}_{2}$ formation are low in aprotic solvents. We have performed calculations of the diffusion barrier of the adsorbed $\mathrm{H}^{*}$ to an adsorbed water layer forming $\mathrm{H}_{3} \mathrm{O}^{+}$over $\mathrm{PdH}(111)$. The calculations show that the barrier is small (about $0.4 \mathrm{eV}$, see the Supporting Information), and we believe that such proton-electron transfer mechanisms could work in parallel with the reaction paths we have discussed here.

\section{CONCLUSIONS}

Herein, we provide a perspective on the reaction mechanism for direct formation of $\mathrm{H}_{2} \mathrm{O}_{2}$ from $\mathrm{H}_{2}$ and $\mathrm{O}_{2}$ over Pd catalysts by the combination of density functional theory calculations and mean-field kinetic modeling. First, the state of the $\mathrm{Pd}$ catalyst under different reaction conditions has been determined by constructing a surface phase diagram with respect to the chemical potential of $\mathrm{H}_{2}$ and $\mathrm{O}_{2}$ at $275 \mathrm{~K}$. It is found that $\beta-\mathrm{PdH}(111)$ with full coverage of hydrogen is the stable phase with 1 atm $\mathrm{H}_{2}$ and $1 \mathrm{~atm} \mathrm{O}_{2}$. Thus, the reaction steps for $\mathrm{H}_{2} \mathrm{O}_{2}$ formation on $\mathrm{Pd}(111)$ and $\beta$ - $\mathrm{PdH}(111)$ are investigated. To model the reactions on the edge sites in a typical Pd nanoparticle, a stepped surface $\operatorname{PdH}(211)$ is employed to construct the reaction landscape. It is found that adsorption of $\mathrm{O}_{2}$ is endothermic on $\mathrm{PdH}(111)$, which results in low $\mathrm{H}_{2} \mathrm{O}_{2}$ production over the extended facet. However, the edge sites of the stepped surface $\mathrm{PdH}(211)$ provide sites to adsorb $\mathrm{O}_{2}$ exothermically, which gives possibilities for $\mathrm{H}_{2} \mathrm{O}_{2}$ formation. Additionally, the decomposition of the intermediate species to $\mathrm{OH}$ groups is kinetically hindered by site blocking of neighboring surface $\mathrm{H}$. The surface hydrogen is, moreover, found to facilitate the desorption of $\mathrm{H}_{2} \mathrm{O}_{2}$, which further prevents the unwanted decomposition of $\mathrm{H}_{2} \mathrm{O}_{2}$. Our findings suggest that undercoordinated sites are active sites for direct $\mathrm{H}_{2} \mathrm{O}_{2}$ formation and highlight the importance of hydrogen coverage on the $\mathrm{Pd}$ catalyst surface. The results imply that the selectivity of the reaction toward $\mathrm{H}_{2} \mathrm{O}_{2}$ can be enhanced by a high partial pressure of $\mathrm{H}_{2}$. In this way, we provide a mechanistic understanding of the intrinsic role of the reactant pressure and the role of undercoordinated sites for direct synthesis of $\mathrm{H}_{2} \mathrm{O}_{2}$ on $\mathrm{Pd}$ catalysts.

\section{ASSOCIATED CONTENT}

\section{SI Supporting Information}

The Supporting Information is available free of charge at https://pubs.acs.org/doi/10.1021/acscatal.0c05548.

Comparison between electronic densities of states for Pd and $\mathrm{PdH}$, scaling relation for $\mathrm{H}-\mathrm{H}$ interaction in the kinetic model, reaction networks, equilibrium coverages, reaction orders, analysis of DRC, and mechanism for $\mathrm{H}$ transfer via an adsorbed water layer (PDF)

\section{AUTHOR INFORMATION}

\section{Corresponding Authors}

Lin Chen - Department of Physics and Competence Centre for Catalysis, Chalmers University of Technology, SE-412 96
Göteborg, Sweden; 이이.org/0000-0002-7905-9587;

Email: clin@chalmers.se

Henrik Grönbeck - Department of Physics and Competence Centre for Catalysis, Chalmers University of Technology, SE41296 Göteborg, Sweden; ○ orcid.org/0000-0002-87092889; Email: ghj@chalmers.se

\section{Author}

J. Will Medlin - Department of Chemical and Biological

Engineering, University of Colorado Boulder, Boulder 80303, Colorado, United States; (1) orcid.org/0000-0003-24042443

Complete contact information is available at:

https://pubs.acs.org/10.1021/acscatal.0c05548

\section{Notes}

The authors declare no competing financial interest.

\section{ACKNOWLEDGMENTS}

Financial support was obtained from the Research Foundation FORMAS (2018-01004) and the Swedish Research Council (2016-05234). The Competence Centre for Catalysis is hosted by Chalmers University of Technology and financially supported by the Swedish Energy Agency and the member companies $\mathrm{AB}$ Volvo, ECAPS $\mathrm{AB}$, Johnson Matthey $\mathrm{AB}$, Preem $A B$, Scania $C V A B$, and Umicore Denmark Aps. The calculations have been performed at C3SE (Göteborg) and PDC (Stockholm) through a SNIC grant.

\section{REFERENCES}

(1) Edwards, J. K.; Solsona, B.; N, E. N.; Carley, A. F.; Herzing, A. A.; Kiely, C. J.; Hutchings, G. J. Switching off hydrogen peroxide hydrogenation in the direct synthesis process. Science 2009, 323, 1037-1041.

(2) Noyori, R.; Aoki, M.; Sato, K. Green oxidation with aqueous hydrogen peroxide. Chem. Commun. 2003, 16, 1977-1986.

(3) Goor, G.; Glenneberg, J.; Jacobi, S. Hydrogen Peroxide. Ullmann's Encyclopedia of Industrial Chemistry; American Cancer Society, 2012; Vol. 18, pp 393-427.

(4) Flaherty, D. W. Direct synthesis of $\mathrm{H}_{2} \mathrm{O}_{2}$ from $\mathrm{H}_{2}$ and $\mathrm{O}_{2}$ on Pd catalysts: Current understanding, outstanding questions, and research needs. ACS Catal. 2018, 8, 1520-1527.

(5) Campos-Martin, J. M.; Blanco-Brieva, G.; Fierro, J. L. G. Hydrogen peroxide synthesis: an outlook beyond the anthraquinone process. Angew. Chem., Int. Ed. 2006, 45, 6962-6984.

(6) Dissanayake, D.; Lunsford, J. The direct formation of $\mathrm{H}_{2} \mathrm{O}_{2}$ from $\mathrm{H}_{2}$ and $\mathrm{O}_{2}$ over colloidal palladium. J. Catal. 2003, 214, 113-120.

(7) Lari, G. M.; Puértolas, B.; Shahrokhi, M.; López, N.; PérezRamírez, J. Hybrid palladium nanoparticles for direct hydrogen peroxide synthesis: the key role of the ligand. Angew. Chem. 2017, 129, 1801-1805.

(8) Liu, Q.; Bauer, J. C.; Schaak, R. E.; Lunsford, J. H. Direct synthesis of $\mathrm{H}_{2} \mathrm{O}_{2}$ from $\mathrm{H}_{2}$ and $\mathrm{O}_{2}$ over $\mathrm{Pd}-\mathrm{Pt} / \mathrm{SiO}_{2}$ bimetallic catalysts in a $\mathrm{H}_{2} \mathrm{SO}_{4}$ /ethanol system. Appl. Catal., A 2008, 339, 130136.

(9) Han, Y.-F.; Zhong, Z.; Ramesh, K.; Chen, F.; Chen, L.; White, T.; Tay, Q.; Yaakub, S. N.; Wang, Z. Au promotional effects on the synthesis of $\mathrm{H}_{2} \mathrm{O}_{2}$ directly from $\mathrm{H}_{2}$ and $\mathrm{O}_{2}$ on supported $\mathrm{Pd}$-Au alloy catalysts. J. Phys. Chem. C 2007, 111, 8410-8413.

(10) Wilson, N. M.; Flaherty, D. W. Mechanism for the direct synthesis of $\mathrm{H}_{2} \mathrm{O}_{2}$ on pd clusters: Heterolytic reaction pathways at the liquid-solid interface. J. Am. Chem. Soc. 2016, 138, 574-586.

(11) Tian, P.; Ouyang, L.; Xu, X.; Ao, C.; Xu, X.; Si, R.; Shen, X.; Lin, M.; Xu, J.; Han, Y.-F. The origin of palladium particle size effects in the direct synthesis of $\mathrm{H}_{2} \mathrm{O}_{2}$ : Is smaller better? J. Catal. 2017, 349, $30-40$. 
(12) Edwards, J. K.; Hutchings, G. J. Palladium and gold-palladium catalysts for the direct synthesis of hydrogen peroxide. Angew. Chem., Int. Ed. 2008, 47, 9192-9198.

(13) F de L e Freitas, L.; Puértolas, B.; Zhang, J.; Wang, B.; Hoffman, A. S.; Bare, S. R.; Pérez-Ramírez, J.; Medlin, J. W.; Nikolla, E. Tunable catalytic performance of palladium nanoparticles for $\mathrm{H}_{2} \mathrm{O}_{2}$ direct synthesis via surface-bound ligands. ACS Catal. 2020, 10, 5202-5207.

(14) Liu, Q.; Lunsford, J. H. Controlling factors in the direct formation of $\mathrm{H}_{2} \mathrm{O}_{2}$ from $\mathrm{H}_{2}$ and $\mathrm{O}_{2}$ over a $\mathrm{Pd} / \mathrm{SiO}_{2}$ catalyst in ethanol. Appl. Catal., A 2006, 314, 94-100.

(15) Doronkin, D. E.; Wang, S.; Sharapa, D. I.; Deschner, B. J.; Sheppard, T. L.; Zimina, A.; Studt, F.; Dittmeyer, R.; Behrens, S.; Grunwaldt, J.-D. Dynamic structural changes of supported Pd, PdSn, and PdIn nanoparticles during continuous flow high pressure direct $\mathrm{H}_{2} \mathrm{O}_{2}$ synthesis. Catal. Sci. Technol. 2020, 10, 4726-4742.

(16) Selinsek, M.; Deschner, B. J.; Doronkin, D. E.; Sheppard, T. L.; Grunwaldt, J.-D.; Dittmeyer, R. Revealing the structure and mechanism of palladium during direct synthesis of hydrogen peroxide in continuous flow using operando spectroscopy. ACS Catal. 2018, 8, $2546-2557$.

(17) Samanta, C. Direct synthesis of hydrogen peroxide from hydrogen and oxygen: An overview of recent developments in the process. Appl. Catal., A 2008, 350, 133-149.

(18) Guo, X.; Hoffman, A.; Yates, J. T., Jr. Adsorption kinetics and isotopic equilibration of oxygen adsorbed on the Pd (111) surface. $J$. Chem. Phys. 1989, 90, 5787-5792.

(19) Rose, M. K.; Borg, A.; Dunphy, J. C.; Mitsui, T.; Ogletree, D. F.; Salmeron, M. Chemisorption and dissociation of $\mathrm{O}_{2}$ on $\mathrm{Pd}$ (111) studied by STM. Surf. Sci. 2003, 547, 162-170.

(20) Rose, M. K.; Borg, A.; Dunphy, J. C.; Mitsui, T.; Ogletree, D. F.; Salmeron, M. Chemisorption of atomic oxygen on Pd (111) studied by STM. Surf. Sci. 2004, 561, 69-78.

(21) Song, X.; Sun, K.; Hao, X.; Su, H.-Y.; Ma, X.; Xu, Y. FacetDependent of Catalytic Selectivity: The Case of $\mathrm{H}_{2} \mathrm{O}_{2}$ Direct Synthesis on Pd Surfaces. J. Phys. Chem. C 2019, 123, 26324.

(22) Kresse, G.; Hafner, J. Ab Initio Molecular Dynamics for Openshell Transition Metals. Phys. Rev. B: Condens. Matter Mater. Phys. 1993, 48, 13115-13118.

(23) Kresse, G.; Hafner, J. Ab Initio Molecular-dynamics Simulation of the Liquid-metal-amorphous-semiconductor Transition in Germanium. Phys. Rev. B: Condens. Matter Mater. Phys. 1994, 49, 14251-14269.

(24) Kresse, G.; Furthmüller, J. Efficient Iterative Schemes for Ab Initio Total-energy Calculations Using a Plane-wave Basis Set. Phys. Rev. B: Condens. Matter Mater. Phys. 1996, 54, 11169-11186.

(25) Kresse, G.; Furthmüller, J. Efficiency of Ab-initio Total Energy Calculations for Metals and Semiconductors Using a Plane-wave Basis Set. J. Comput. Mater. Sci. 1996, 6, 15-50.

(26) We used VASP version 5.4.1.

(27) Blöchl, P. E. Projector Augmented-wave Method. Phys. Rev. B: Condens. Matter Mater. Phys. 1994, 50, 17953-17979.

(28) Kresse, G.; Joubert, D. From Ultrasoft Pseudopotentials to the Projector Augmented-wave Method. Phys. Rev. B: Condens. Matter Mater. Phys. 1999, 59, 1758-1775.

(29) Perdew, J. P.; Burke, K.; Ernzerhof, M. Generalized Gradient Approximation Made Simple. Phys. Rev. Lett. 1996, 77, 3865-3868.

(30) Grimme, S.; Antony, J.; Ehrlich, S.; Krieg, H. A Consistent and Accurate ab initio Parametrization of Density Functional Dispersion Correction (DFT-D) for the 94 Elements H-Pu. J. Comput. Chem. 2010, 132, 154104.

(31) Grimme, S.; Ehrlich, S.; Goerigk, L. Effect of the Damping Function in Dispersion Corrected Density Functional Theory. J. Comput. Chem. 2011, 32, 1456-1465.

(32) Schirber, J. E.; Morosin, B. Lattice constants of $\beta-\mathrm{PdH}_{\mathrm{x}}$ and $\beta-\mathrm{PdD}_{\mathrm{x}}$ with $\mathrm{x}$ near 1.0. Phys. Rev. B: Solid State 1975, 12, 117.

(33) Monkhorst, H. J.; Pack, J. D. Special points for Brillouin-zone integrations. Phys. Rev. B: Solid State 1976, 13, 5188-5192.
(34) Teschner, D.; Borsodi, J.; Wootsch, A.; Révay, Z.; Hävecker, M.; Knop-Gericke, A.; Jackson, S. D.; Schlögl, R. The roles of subsurface carbon and hydrogen in palladium-catalyzed alkyne hydrogenation. Science 2008, 320, 86-89.

(35) Hong, S.; Rahman, T. S. Adsorption and diffusion of hydrogen on Pd (211) and Pd (111): Results from first-principles electronic structure calculations. Phys. Rev. B 2007, 75, 155405.

(36) Mills, G.; Jónsson, H.; Schenter, G. K. Reversible Work Transition State Theory: Application to Dissociative Adsorption of Hydrogen. Surf. Sci. 1995, 324, 305-337.

(37) Henkelman, G.; Jónsson, H. Improved Tangent Estimate in the Nudged Elastic Band Method for Finding Minimum Energy Paths and Saddle Points. J. Chem. Phys. 2000, 113, 9978-9985.

(38) NIST Standard Reference Database.

(39) Rogal, J.; Reuter, K. Ab initio atomistic thermodynamics for surfaces: A primer. Educational Notes RTO-EN-AVT-142: Neuilly-surSeine 2007.

(40) McQuarrie, D. A.; Simon, J. D. Molecular Thermodynamics; University Science Books, 1999.

(41) Chorkendorff, I.; Niemantsverdriet, J. W. Concepts of Modern Catalysis and Kinetics; John Wiley \& Sons, 2017.

(42) Virtanen, P.; Gommers, R.; Oliphant, T. E.; Haberland, M.; Reddy, T.; Cournapeau, D.; Burovski, E.; Peterson, P.; Weckesser, W.; Bright, J.; van der Walt, S. J.; Brett, M.; Wilson, J.; Millman, K. J.; Mayorov, N.; Nelson, A. R. J.; Jones, E.; Kern, R.; Larson, E.; Carey, C. J.; Polat, I.; Feng, Y.; Moore, E. W.; VanderPlas, J.; Laxalde, D.; Perktold, J.; Cimrman, R.; Henriksen, I.; Quintero, E. A.; Harris, C. R.; Archibald, A. M.; Ribeiro, A. H.; Pedregosa, F.; van Mulbregt, P. SciPy 1.0 Contributors, SciPy 1.0: Fundamental Algorithms for Scientific Computing in Python. Nat. Methods 2020, 17, 261-272.

(43) Eyring, $\mathrm{H}$. The activated complex and the absolute rate of chemical reactions. Chem. Rev. 1935, 17, 65-77.

(44) Stoltze, P. Surface Science as the Basis for the Understanding of the Catalytic Synthesis of Ammonia. Phys. Scr. 1987, 36, 824.

(45) Trinchero, A.; Hellman, A.; Grönbeck, H. Methane oxidation over Pd and Pt studied by DFT and kinetic modeling. Surf. Sci. 2013 616, 206-213.

(46) Frieske, H.; Wicke, E. Magnetic susceptibility and equilibrium diagram of $\mathrm{PdH}_{n}$. Ber. Bunsen-Ges. 1973, 77, 48-52.

(47) Johansson, M.; Skúlason, E.; Nielsen, G.; Murphy, S.; Nielsen, R. M.; Chorkendorff, I. Hydrogen adsorption on palladium and palladium hydride at 1 bar. Surf. Sci. 2010, 604, 718-729.

(48) Lundgren, E.; Kresse, G.; Klein, C.; Borg, M.; Andersen, J.; De Santis, M.; Gauthier, Y.; Konvicka, C.; Schmid, M.; Varga, P. Twodimensional oxide on Pd (111). Phys. Rev. Lett. 2002, 88, 246103.

(49) Ketteler, G.; Ogletree, D. F.; Bluhm, H.; Liu, H.; Hebenstreit, E. L. D.; Salmeron, M. In situ spectroscopic study of the oxidation and reduction of Pd (111). J. Am. Chem. Soc. 2005, 127, 1826918273.

(50) Jewell, L.; Davis, B. Review of absorption and adsorption in the hydrogen-palladium system. Appl. Catal., A 2006, 310, 1-15.

(51) Mitsui, T.; Rose, M. K.; Fomin, E.; Ogletree, D. F.; Salmeron, M. A scanning tunneling microscopy study of the reaction between hydrogen and oxygen to form water on Pd (111). J. Chem. Phys. 2002, $117,5855-5858$.

(52) Hammer, B. Special sites at noble and late transition metal catalysts. Top. Catal. 2006, 37, 3-16.

(53) Viñes, F.; Gomes, J. R. B.; Illas, F. Understanding the reactivity of metallic nanoparticles: beyond the extended surface model for catalysis. Chem. Soc. Rev. 2014, 43, 4922-4939.

(54) Landon, P.; Collier, P. J.; Carley, A. F.; Chadwick, D.; Papworth, A. J.; Burrows, A.; Kiely, C. J.; Hutchings, G. J. Direct synthesis of hydrogen peroxide from $\mathrm{H}_{2}$ and $\mathrm{O}_{2}$ using $\mathrm{Pd}$ and $\mathrm{Au}$ catalysts. Phys. Chem. Chem. Phys. 2003, 5, 1917-1923.

(55) Campbell, C. T. The Degree of Rate Control: A Powerful Tool for Catalysis Research. ACS Catal. 2017, 7, 2770.

(56) Kumar, G.; Van Cleve, T.; Park, J.; Van Duin, A.; Medlin, J. W.; Janik, M. J. Thermodynamics of alkanethiol self-assembled monolayer assembly on Pd surfaces. Langmuir 2018, 34, 6346-6357. 
(57) Mark, L. O.; Zhu, C.; Medlin, J. W.; Heinz, H. Understanding the surface reactivity of ligand-protected metal nanoparticles for biomass upgrading. ACS Catal. 2020, 10, 5462-5474.

(58) Schoenbaum, C. A.; Schwartz, D. K.; Medlin, J. W. Controlling the surface environment of heterogeneous catalysts using selfassembled monolayers. Acc. Chem. Res. 2014, 47, 1438-1445.

(59) Lunsford, J. H. The direct formation of $\mathrm{H}_{2} \mathrm{O}_{2}$ from $\mathrm{H}_{2}$ and $\mathrm{O}_{2}$ over palladium catalysts. J. Catal. 2003, 216, 455-460. 